\title{
ELECTROKINETIC MIGRATION STUDIES ON REMOVAL OF CHROMIUM AND URANYL IONS FROM 904-A TRENCH SOIL (U)
}

by J.P. Bibler

Westinghouse Savannah River Company

Savannah River Site

Aiken, South Carolina 29808

Other Authors:

T. F. Meaker

(WSRC)

A. B. O'Steen

(WSRC)
WSRC-RP--92-1207

DE93 005074

This paper was prepared in connection with work done under Contract No. DE-AC09-89SR18035 with the U.S. Department of Energy. By acceptance of this paper, the publisher and/or recipient acknowledges the U. S. Government's right to retain a nonexclusive, royalty-free license in and to any copyright covering this paper, along with the right to reproduce and to authorize others to reproduce all or part of the copyrighted paper. 


\section{DISCLAIMER}

This report was prepared as an account of work sponsored by an agency of the United States Government. Neither the United States Government nor any agency thereof, nor any of their employees, makes any warranty, express or implied, or assumes any legal liability or responsibility for the accuracy, completeness, or usefulness of any information, apparatus, product, or process disclosed, or represents that its use would not infringe privately owned rights. Reference herein to any specific commercial product, process, or service by trade name, trademark, manufacturer, or otherwise does not necessarily constitute or imply its endorsement, recommendation, or favoring by the United States Government or any agency thereof. The views and opinions of authors expressed herein do not necessarily state or reflect those of the United States Government or any agency thereof.

This report has been reproduced directly from the best available copy.

Available to DOE and DOE contractors from the Office of Scientific and Technical Information, P.O. Box 62, Oak Ridge, TN 37831; prices available from (615) 576-8401, FTS 626-8401.

Available to the public from the National Technical Information Service, U.S. Department of Commerce, 5285 Port Royal Rd., Springfield, VA 22161. 
WESTINGHOUSE SAVANNAH RIVIER COMPANY SAVANNAH RIVER TECHNOLOGY CENTER

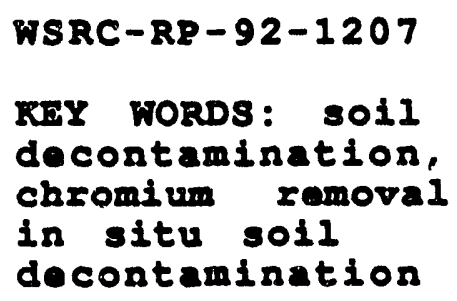

September 30, 1992

TO:

\section{DISTRIBUTION}

FROM: J.P. BIBLER, 773-ג $\mathscr{\text { PI }}$

T.F. MEATER

A.B. OSTEEN, 773-A COO

\section{ELECTROKINETIC MIGRATION STUDIES ON RMMOVAL OF CAROMIUN AND URANYL IONS FROM 904-A TRENCE SOII (U)}

The attached report represents work performed at the savannah River Technology Center (SRTC) under ADS/TTP \# SR-122-11, funded by the Office of Technology Development. It fulfills a milestone requirement for that ADS/TTP.

Mr. Meaker was a Teacher Research Associate (TRAC) in the U. $S$. Department of Energy Office of Energy Research Program.

Attachment 
WESTINGHOUSE SAVANNAH RIVER COMPANY SAVANNAH RIVER TECHNOLOGY CENTER
WSRC-RP-92-1207

\section{REY KORDS: SOII decontamination, chromium removal, in situ soil decontamination}

September 30,1992

TO: D.L. FISH, 773-A

FROM: J.P. BIBLER, 773-A, T.F.MEAKER, A.B. OSTEEN, 773-A

\section{ELECTROKINETIC MIGRATION STUDIES ON REMOVAI OF CHROMIUM AND URANYI IONS FROM 904-A TRENCE SOIL (U)}

\subsection{SUMARAR}

This report describes a laboratory-scale study, in which electrokinetic migration technology was used to remove chromium and uranium, as well as other lons, from soll taken from a bore hole adjacent to the 904-A trench at the Savannah River Technology Center. Imposition of an electric current on humid (not saturated) soil successfully caused cations to migrate through the pore water of the soil to the cathode, where they were captured in an ISOLOCK ${ }^{\mathrm{TM}}$ polymer matrix and in a cation exchange resin incorporated in the polymer. Chemicals circulated through the anode/polymer and cathode/polymer were able to control pH excursions in the electrokinetic cells by reacting with the $\mathrm{H}^{+}$ and $\mathrm{OH}^{-}$generated at the anode and cathode, respectively. The study indicates that ions adsorbed on the surface of the soil as well as those in the pores of soll particles can be caused to migrate through the soll to an appropriate electrode. After 10 days of operation at $20-25 \mathrm{~V}$ and $2 \mathrm{~mA}$, approximately $65 \%$ of the chromium was removed from two $3.5 \mathrm{~kg}$ soil samples. A 57 \& removal of uranium was achieved. The study shows that electrokinetic migration, using the ISOLOCK ${ }^{\mathrm{M}}$ polymer will be effective as an in situ treatment method for the removal of metal ion contaminants in soil adjacent to the 904-A trench.

\subsection{INWRODUCTION}

The 904-A trench, which includes the concrete secondary containment structure and the enclosed piping and piping supports, has been used since 1953 to transfer low level contaminated liquids from the Savannah River Technology Center (SRTC), buildings $773-\mathrm{A}$ and $779-\mathrm{A}$, to the 776-2A storage tanks for disposal as radioactive wastes (Figure 1 ). The trench, and some of the soll around it, is known to contain residual radioactivity and chemical contamination from a spill that occurred in 1971 . Analysis of core samples (Figure 2) taken around the trench in 1984 indicated elevated concentrations of some chemical species 
D.I. FISH

WSRC-RP-92-1207

September 30, 1992

Page 2 of 54

(Table 1) relative to uncontaminated soil from the same region. Core samples were taken again this year along the 904-A trench for analysis to determine the location and amount of soil contamination that still exists.

Table 1. Low Level Contamination Along the 904-A Trench (1984)1

Species "Elevated Concentrations"

"Background Concentrations"

Inorganics, $\mu g / g$

arsenic
barium
cadmium
chromium
copper
iron
magnesium
manganese
nickel
lead
Zinc

$\begin{array}{ll}0.4 & \text { to } 2.4 \\ 5 & \text { to } 16 \\ 2.5 & \text { to } 6 \\ 15 & \text { to } 40 \\ 3 & \text { to } 5 \\ 1000 & \text { to } 25000 \\ 100 & \text { to } 200 \\ 30 & \text { to } 40 \\ 3 & \text { to } 8 \\ 8 & \text { to } 20 \\ 50 & \text { to } 200\end{array}$

$<0.2$

2 to 5

$<1$

1 to 3

1 to 2

1000 to 3000

20 to 50

5 to 10

$<1$

$<2$

20 to 40

Radionuclides, $\mathrm{pCi} / \mathrm{g}$

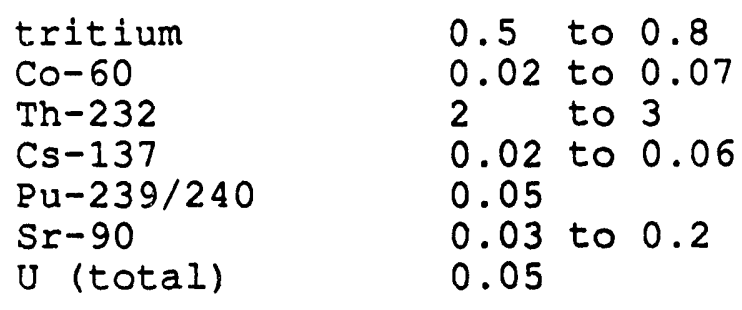

0.07 to 0.5

$<0.02$

1.5 to 2

$<0.02$

$<0.05$

$<0.03$

$<0.05$ 




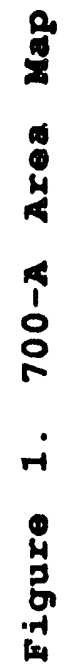




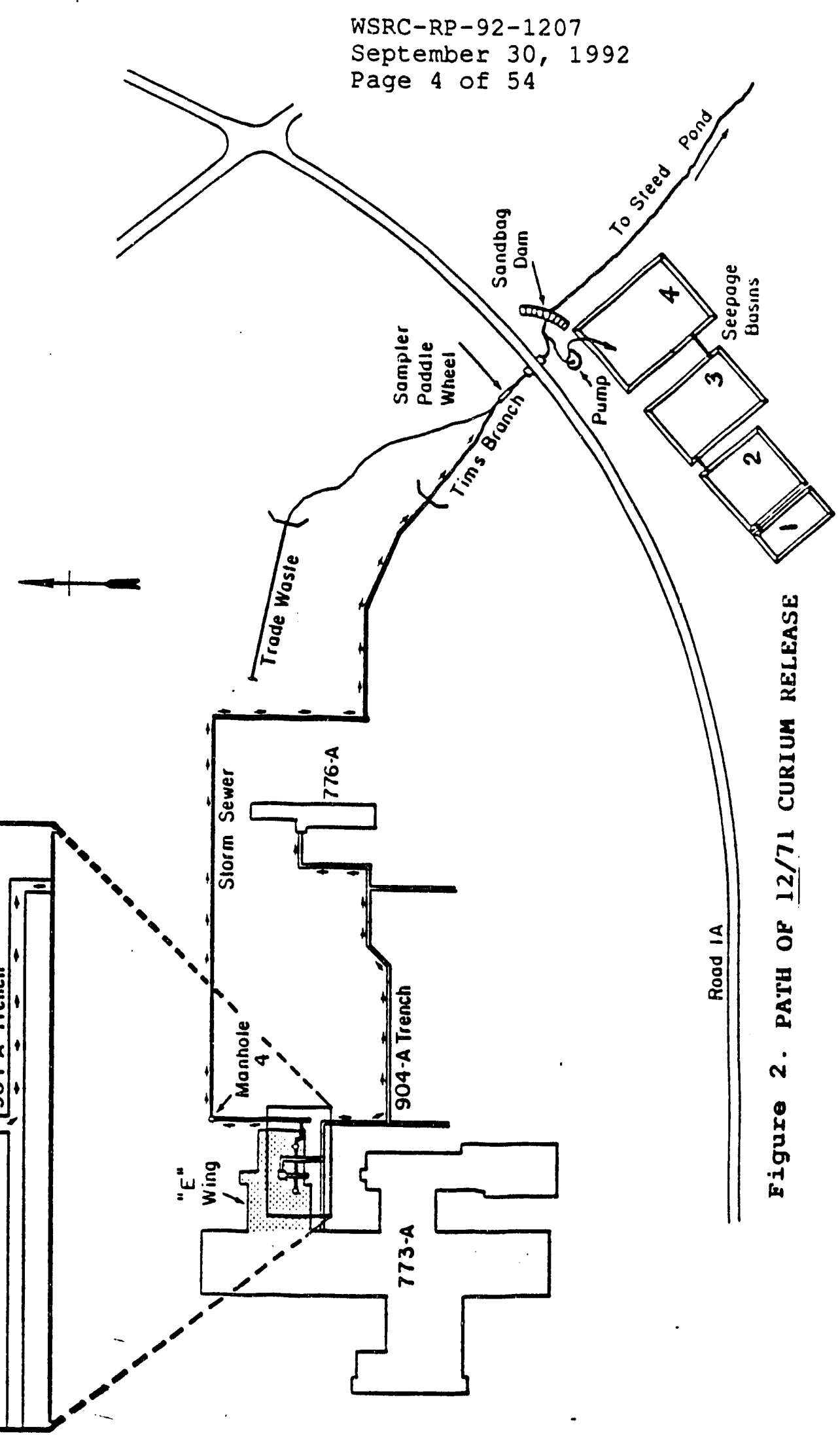


D.I. FISH

WSRC-RP-92-1207

September 30, 1992

Page 5 of 54

It has been proposed to continue to use, or to replace all or parts of, the trench to transfer liquid wastes to the waste tank farm at 776-A. The 904-A trench resides in an area that has been designated as a Comprehensive Environmental Response, Compensation, and liability Act (CERCLA) site. Also, the waste tanks into which the piping in the trench empties are permitted under the Resource Conservation and Recovery Act (RCRA). Because of the contamination from the spill and because the trench experiences a significant inleakage of groundwater, it does not meet RCRA standards for secondary containment. Remedial action may be required for both conditions. As part of that remedial action, excavation of all or part of the trench will be necessary. Excavated soils that are found to contain excessive amounts of hazardous or radioactive materials will have to be disposed of and replaced with uncontaminated soil.

This study was undertaken to evaluate a technology that has the potential to effect in situ decontamination of the soil. If it can be demonstrated that the soil can be decontaminated in place prior to repair of the trench, the cost of disposing and replacement of the soil around the trench may be avoided. One core sample, SBA-1 (See Figure 3), was obtained for testing of electrokinetic migration technology in lab-scale experiments for the removal of chromium and uranium from the soil. It was originally planned to study the removal of radioactive cesium during this test, but radiochemical analysis of soil leachates showed that Cs-137 was no longer present at detectable levels $(6 \mathrm{E}-5 \mu \mathrm{Ci} / \mathrm{kg}$ soil leached; $3 \mathrm{E}-5 \mu \mathrm{Ci} / \mathrm{mL}$ in the leachate).

\subsection{ELECTROKINETIC MIGRATION TECHNOLOGY}

Electrokinetic remediation of soil has been demonstrated for saturated and unsaturated soils ${ }^{2-20}$. In electrokinetic remediation, electrodes are implanted in soil and a direct current is imposed between the electrodes. The application of direct current leads to three effects (Figure 4): lonic species in the soil-water solution will migrate to the oppositely charged electrode

(electromigration), charged solids will migrate to the oppositely charged electrode (electrophoresis), and a bulk flow of water is induced toward the cathode (electroosmosis). The dominant process among these three in unsaturated soll has been demonstrated to be electromigration. ${ }^{2}$ The combination of these phenomena leads to a movement of contaminant ions toward one or other of the electrodes electrodes 


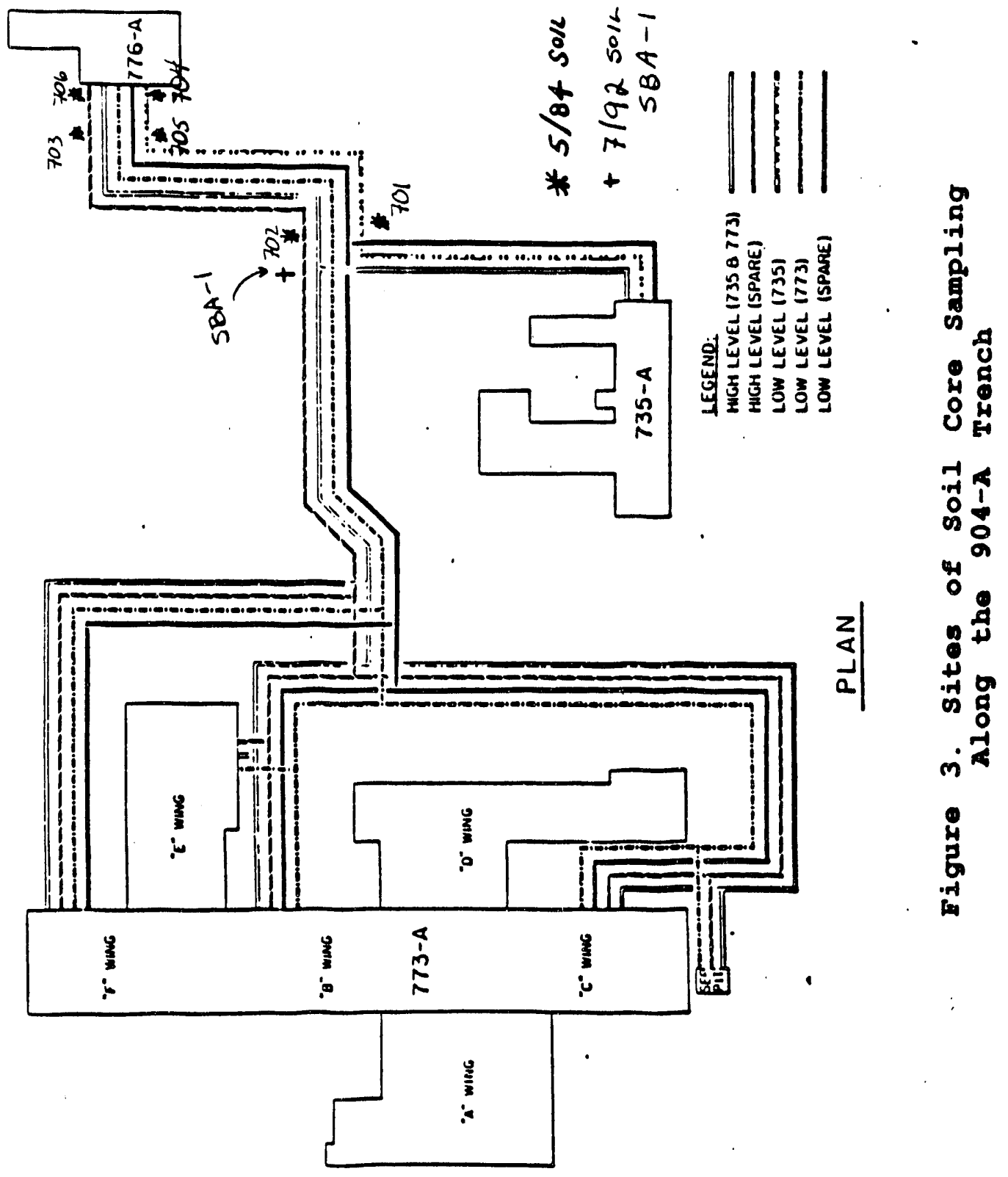




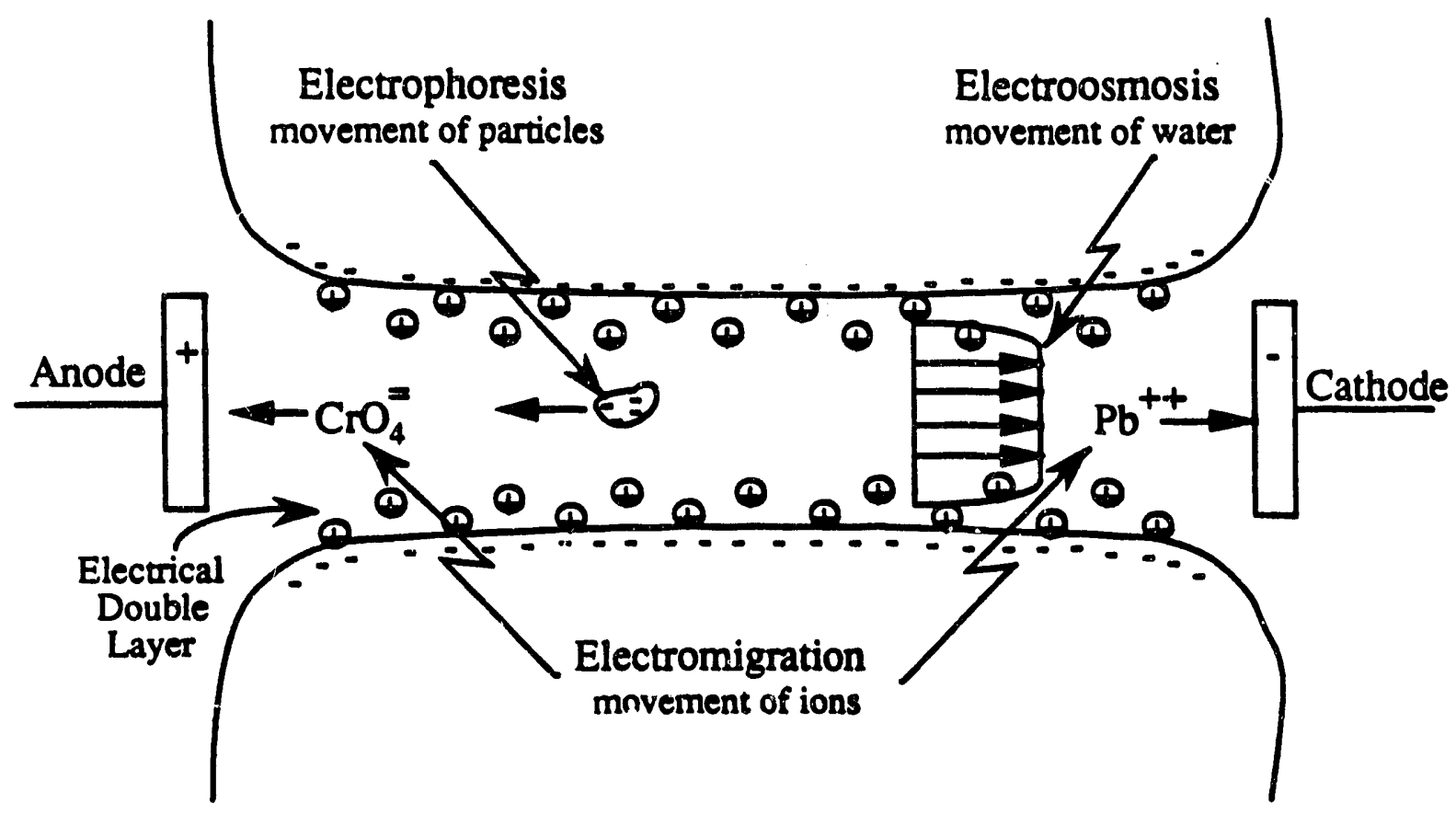
Figure 4. Electrokinetic Phenomnna Pertinent to In situ
Remediation 
where they may be removed from the ground water by a variety of methods. Among these are electroplating at the electrode, precipitation or co-precipitation near the electrode, pumping of water near the electrode to bring a solution of the ions to the surface, or stabilizing the ions in a solid matrix such as an ion exchange resin.

\subsection{EXPERIMENTAI}

In this experiment, humid soil with an unbound water content of approximately $10 \%$ by weight was subjected to treatment by direct current. The $\mathrm{pH}$ at the anode was controlled by the circulation of a saturated CaO solution through a polymer (the ISOLOCK ${ }^{\mathrm{TM}}$ polymer that is the property of IsotrontM Corp.) surrounding the electrode. Similarly, the $\mathrm{pH}$ at the cathode was controlled by circulation of a $1 \mathrm{M}$ acetic acid solution.

\subsection{Soil Collection}

Soil cuttings from the $14^{\prime}-16^{\prime}$ depth of borehole SBA-1, along the 904-A Trench, were collected (See Appendix 1). These cuttings contained primarily soil from that depth but also some of the soil removed from all levels above 14 feet. A 2'x 3" split spoon, lined with a $2^{\prime} \times 2.5^{\prime \prime}$ plastic inner sleeve, was used to retrieve soil exclusively from the 14'-16' layer. Soil was packaged in plastic bags to prevent evaporation of the moisture and transported to SRTC for analyses and testing.

\subsection{Soil Characterization}

\subsubsection{Moisture Content}

Unsieved samples of the soil cuttings and of the soil in the split spoon were weighed and air-dried to constant weight at $23^{\circ} \mathrm{C}$. The weight percent water associated with the soil was computed. Bound water content was determined by placing weighed samples of airdried split spoon soil in an oven at $107^{\circ} \mathrm{C}$ until they had reached constant weight.

\subsubsection{Resistance of the split spoon soil sample}

The sample taken in the split spoon was contained in the plastic liner and protected from drying out by its packaging in a plastic bag. A special apparatus, designed by Isotron TM Corp. (Eigure 5), was used to measure the conductivity of the soll. The soil at 
each end of the liner was moistened slightly with deionized water to assure conductance. Voltage was increased from 2 to 20 volts in two volt increments. Ammeter readings were taken every 30 seconds at each voltage setiing until current stabilized. After the current stabilized, the voltage was increased another 2 volts and the procedure was repeated. The observed current, in $\mathrm{mA}$, from each of these steps was plotted versus the voltage applied to determine the resistance, $R$.

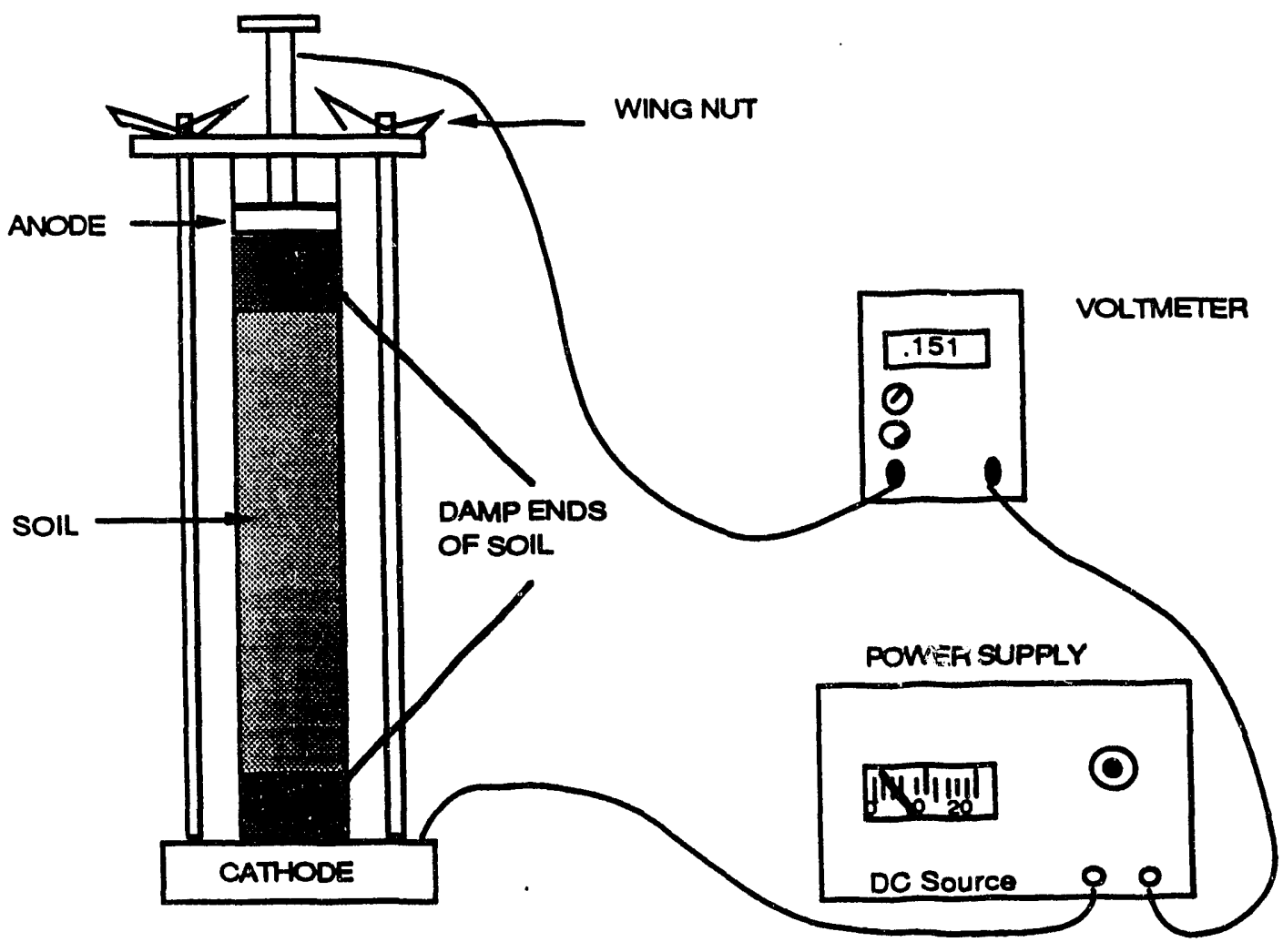

Figure 5. Conductance Apparatus 
D.I. FISH

WSRC-RP-92-1207

September 30, 1992

Page 10 of 54

\subsubsection{Soil Homogenization}

The soil cuttings, after air-drying, were processed through a series of standard sieves. The fractions collected were $<20$ mesh $(<850 \mu \mathrm{m}), 20-40$ mesh $(850-425 \mu \mathrm{m}), 40-60$ mesh $(425-250 \mu \mathrm{m})$, and

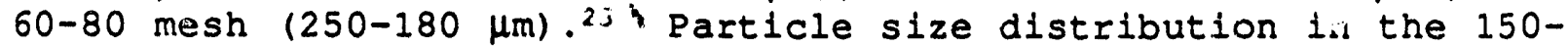
$600 \mu \mathrm{m}$ region was determined for each fraction using a Brinkman particle size analyzer. Samples of each of these fractions was sent to the SRTC Analytical Development section (ADS) for X-ray diffraction and fluorescence analyses, and inspection using a scanning electron microscope. The drying, sieving, and analytical procedures just described were also applied to the sample of soil obtained in the split spoon.

\subsubsection{Jeaching of soils}

Five one-gram samples of air-dried soil from the 20-40 mesh fraction of both cuttings soll and split spoon soil were leached using $20 \mathrm{~mL}$ of $16 \mathrm{M} \mathrm{HNO}_{3}$ for 48 hours at $23^{\circ} \mathrm{C}$. After that time, the leachate was separated from the soil by passing the mixture through a $0.45 \mu \mathrm{m}$ filter. The leachate was analyzed by ADS using the following "routine customer assisted" analytical techniques"2: ICPES (inductively coupled plasma atomic emission spectroscopy) for chromium and several other metals, UChemcheck ${ }^{\mathrm{TM}}$ fluorescence spectrophotometry for total uranium content, and $\gamma$-scan and gross $\alpha$-counting for radionuclides. Samples were also leached in similar fashion in $30 \mathrm{~mL}$ of aqua regia ( 2 volumes $16 \mathrm{M} \mathrm{HNO}_{3}$ and 3 volumes $12 \mathrm{M} \mathrm{HCl}$ ). After filtration, the aqua regia leachate was analyzed by ICPES.

Concentrations in the leachate were back-calculated to yield a concentration for each species identified in the soil.

\subsubsection{Bulk Density of soils}

The bulk density, the volume occupied by 1 gram of air-dried soil when saturated, was determined. A weighed sample of 20-40 mesh air-dried soil was placed in a $10 \mathrm{~mL}$. graduate cylinder and covered with deionized water. The mixture was allowed to stand for 24 hours, after which the volume of the moist soil was recorded. 


\subsection{Operation of the 1-D Electrokinetic Cell}

\subsubsection{Cell Design}

Two one-dimensional electrokinetic cells were assembled as shown in Figure 6. The cell container was a plastic tub (Eigure 7). A cathode electrode assembly, consisting of a mild steel wire mesh electrode in ISOLUCK ${ }^{\mathrm{TM}}$ polymer that was impregnated with Duolite ${ }^{\mathrm{TM}}$ GT -73 cation exchange resin was placed at one end of the tub. The anode assembly, a titanium-coated iridium oxide mesh electrode in ISOLOCK ${ }^{\mathrm{TM}}$ polymer, was placed at the other end. Both polymers contained inlet and outlet tubes associated with a small well in the polymer, through which $1 \mathrm{M}$ acetic acld (at the cathode) and saturated CaO (at the anode) were circulated by means of a peristaltic pump in order to control pH at the electrodes. Soil was placed between the electrode assemblies and a current was passed through the soil. Current and voltage were continuously monitored. Voltage was maintained as close to $25 \mathrm{~V}$ as possible, though voltage fluctuated over a 10-day period of operation between 20 and $25 \mathrm{~V}$. Current was steady at $2 \mathrm{~mA}$ throughout for both cells. During operation, the top of the soll was covered with plastic to prevent evaporation at the surface of the soil.

\subsubsection{Soil Proparation}

Two 3139 gram batches of air-dried 20-40 mesh cuttings soil were mixed carefully with 361 grams of deionized watex to restore the weight percent water in the soil to $10.3 \%$. The moistened soil was allowed to equilibrate in a plastic bag for several days. The moistened soil was placed in the cell tubs between the electrode assemblies just before oryeration of the cells. Plastic was placed over the soil during opesation to prevent evaporation.

\subsubsection{Sampling of soli in the Cell}

After the cells had operated for a desired amount of time, the current was discontinued and the soil was sampled to identify any changes that had taken place during the operation. Approximate 5gram samples were retrieved $1 \mathrm{~cm}$ from the anode assembly, $1 \mathrm{~cm}$ from the cishode assembly, and in the middle of the cell, all from a depth of about $2 \mathrm{~cm}$. Only $150 \mathrm{~g}(0.04 \%)$ of the original $3.5 \mathrm{~kg}$ of solid were lost to sampling. The $\mathrm{pH}$ of these samples was checked using $\mathrm{pH}$ indicator paper. The moisture content of the samples was 


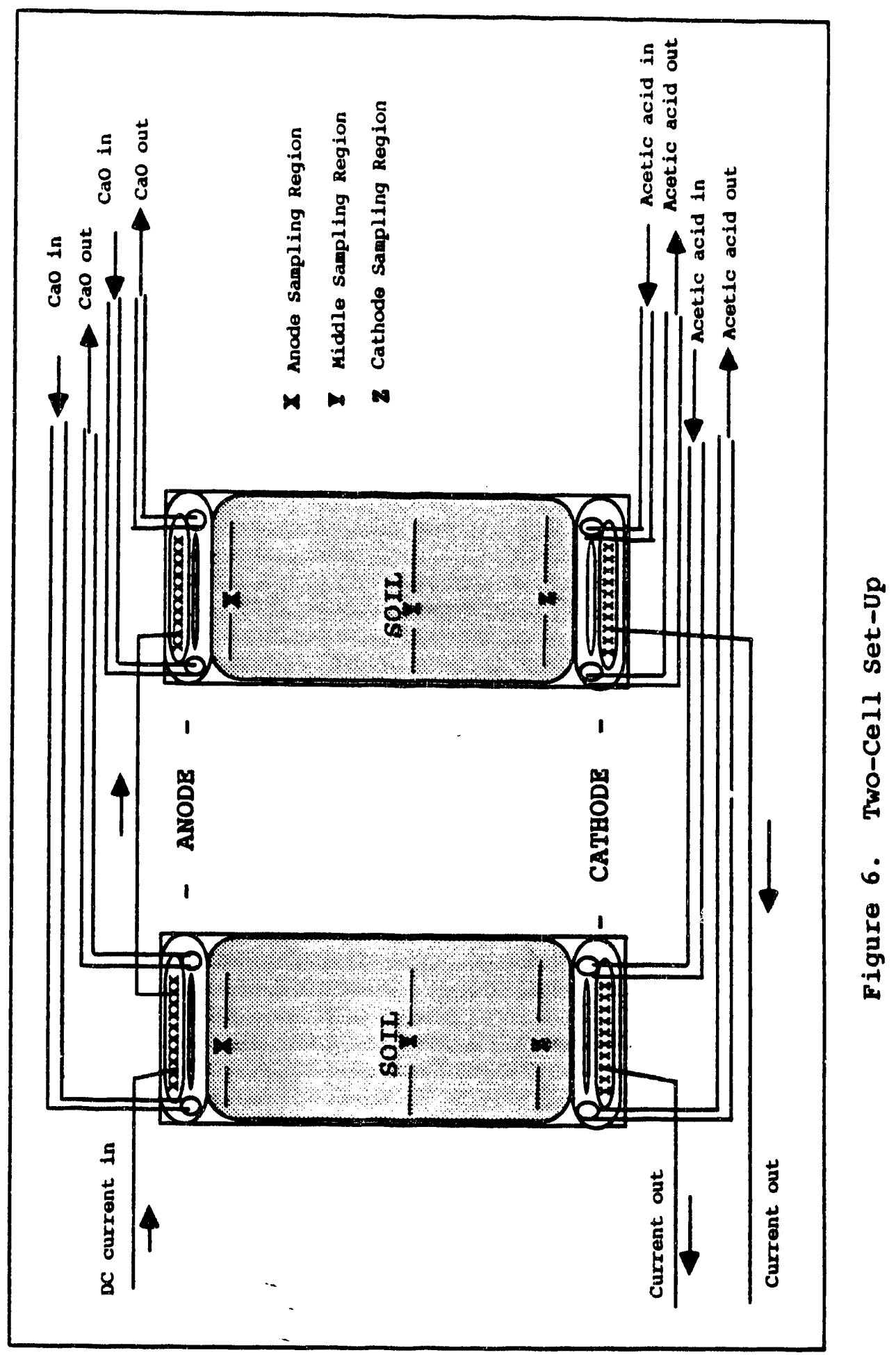


WSRC-RP - 92- 1207

September 30, 1992

Page 13 of 54

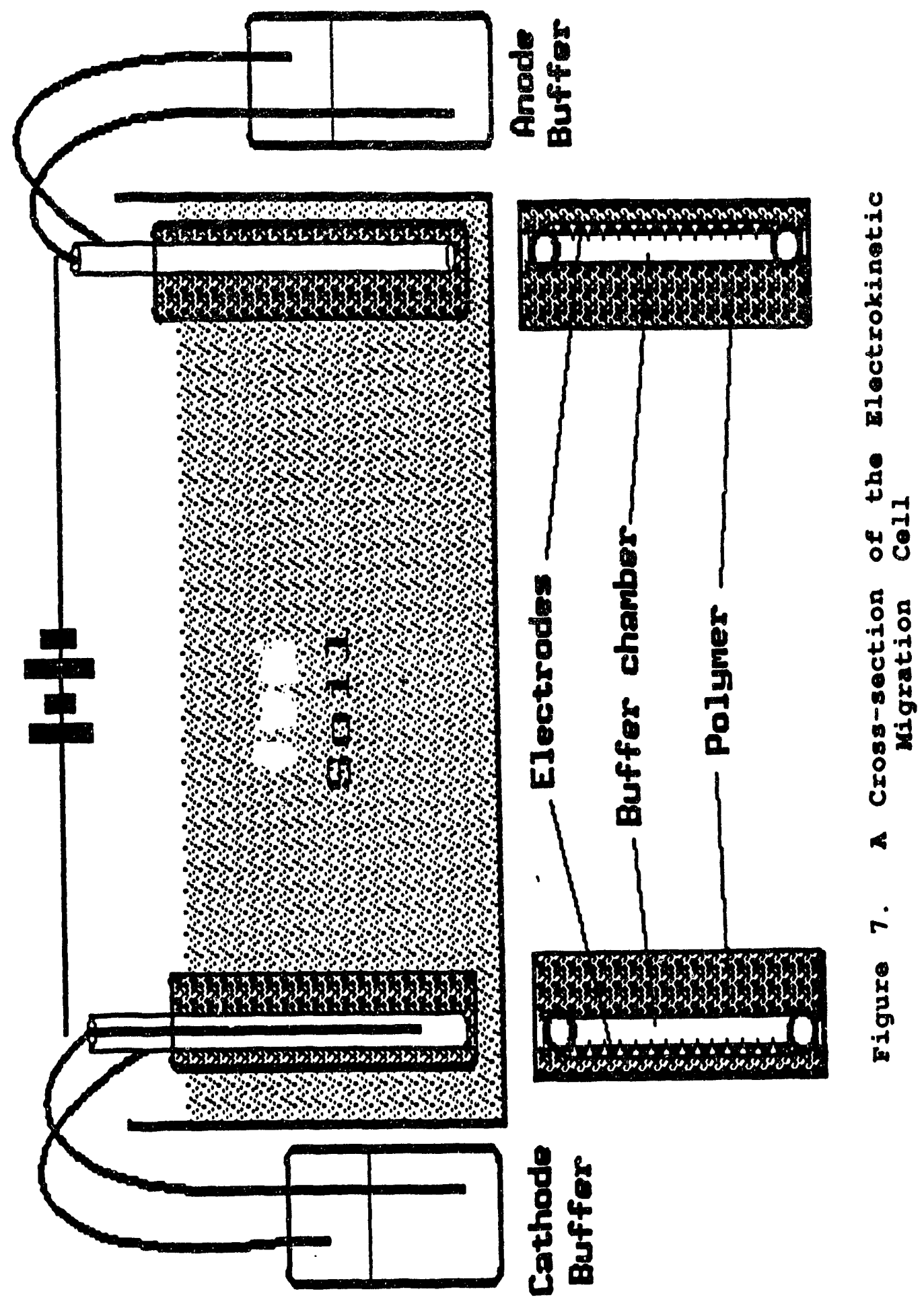


D.I. FISH

WSRC-RP-92-1207

September 30, 1992

Page 14 of 54

determined as noted in section 4.2.1, above. Then, weighed fractions of the air-dried samples were leached with $16 \mathrm{M} \mathrm{HNO}$ or aqua regia, as described in section 4.2.4, and sent for metals analysis by ICPES and UChen check ${ }^{\mathrm{TM}}$. Aqueous leachates were analyzed for anion content by ion ch:omatography (IC).

After sampling, the soil bec' in the cell was smoothed to fill the voids created by sampling an the cell was returned to service.

\subsubsection{Leaching Polymer and Electrodes}

After the cells were shut down and dismantled, weighed pieces of the anode and cathode and their polymers, including polymer containing resin, were leached in aqua regia. Leachates were sent for analysis by ICPES. UChemcheck methods for total uranium were found to be invalid in the presence of the amount of chloride present in the aqua regia.

\subsection{RESULTS}

\subsection{Soil Characterization}

Table 2 gives some basic properties of unsieved soil from the split spoon and of 20-40 mesh cuttings soil.

Table 2. Some Physical Properties of Solls Used in This Study

\begin{tabular}{|c|c|c|c|c|}
\hline Soil & $\mathrm{OH}$ & wt $*$ water & wt 8 bound water & Bulk density \\
\hline $\begin{array}{c}\text { Split Spoon, } \\
\text { unseived }\end{array}$ & 6 & 11.44 & 0.80 & $1.3 \mathrm{~g} / \mathrm{mL}$ \\
\hline $\begin{array}{l}\text { Cuttings, } \\
20-40 \text { mesh }\end{array}$ & 6 & 10.34 & 0.78 & $1.3 \mathrm{~g} / \mathrm{ml}$ \\
\hline
\end{tabular}

The X-ray diffraction results, identifying crystalline components in four sized fractions of soil found in the split spoon, are given in Table 3. Iron oxide/hydroxide is also present in the soils but was either not concentrated enough or in sufficient quantity of a crystalline form to produce a signal in the $x$-ray 
spectrum. Also found in Table 3 are metals in the soil, identified in $\mathrm{X}$-ray fluorescence spectra.

Table 3. X-ray Data for Sieved split spoon soil

\begin{tabular}{|c|c|c|c|c|}
\hline Mesh Size & wets & $\begin{array}{l}\text { grams } \\
\text { of totall }\end{array}$ & $\begin{array}{c}\text { Compounds } \\
\text { Identified by } \\
\text { x-Ray Diffraction }\end{array}$ & $\begin{array}{c}\text { Metals } \\
\text { Identified by } \\
\text { X-Ray Eluerescence }\end{array}$ \\
\hline$>20$ & 75 & $(3.28)$ & $\begin{array}{l}\text { Silicon oxide/quartz, } \\
\text { Kaolinite-1A, } \\
\text { albite, (crystalline) }\end{array}$ & $\begin{array}{l}\mathrm{Fe}, \mathrm{K}, \mathrm{Ca}, \mathrm{Ti}, \mathrm{Cr} \\
\mathrm{Cu}, \mathrm{Zn}, \mathrm{Ni}, \mathrm{Pb}, \mathrm{Th} \\
\mathrm{Sr}, \mathrm{Zr}, \mathrm{Ba}, \mathrm{Nb}, \mathrm{Ce}\end{array}$ \\
\hline $20-40$ & 2,000 & $(85.98)$ & $\begin{array}{l}\text { Silicon oxide/quartz, } \\
\text { Kaolinite-1A }\end{array}$ & $\begin{array}{l}\mathrm{Fe}, \mathrm{K}, \mathrm{Ca}, \mathrm{Ti}, \mathrm{Cr} \\
\mathrm{Cu}, \mathrm{Zn}, \mathrm{Ni}, \mathrm{Pb}, \mathrm{Nb} \\
\mathrm{Sr}, \mathrm{Zr}, \mathrm{Ba}, \mathrm{Th}, \mathrm{Ce}\end{array}$ \\
\hline $40-60$ & 250 & $(10.7 \%)$ & $\begin{array}{l}\text { Silicon oxide/quartz, } \\
\text { Kaolinite-1A, } \\
\text { Illite-1M }\end{array}$ & $\begin{array}{l}\mathrm{Fe}, \mathrm{K}, \mathrm{Ca}, \mathrm{Ti}, \mathrm{Cr} \\
\mathrm{Ci}, \mathrm{Zn}, \mathrm{Ni}, \mathrm{Pb}, \mathrm{Th} \\
\mathrm{Sr}, \mathrm{Zr}, \mathrm{Ba}, \mathrm{Nb}, \mathrm{Ce}\end{array}$ \\
\hline $60-80$ & 30 & $(0.138)$ & $\begin{array}{l}\text { Silicon oxide/quartz, } \\
\text { Kaolinite-1A, } \\
\text { Illite-1M }\end{array}$ & $\begin{array}{l}\mathrm{Fe}, \mathrm{K}, \mathrm{Ca}, \mathrm{Ti}, \mathrm{Cr} \\
\mathrm{Cu}, \mathrm{Zn}, \mathrm{Ni}, \mathrm{Pb}, \mathrm{Th} \\
\mathrm{Sr}, \mathrm{Zr}, \mathrm{Ba}, \mathrm{Nb}, \mathrm{Ce}\end{array}$ \\
\hline
\end{tabular}

Note: Kaolinite-1A is aluminum silicate hydrate Illite-1M is potassium aluminum silicate hydroxide Albite is a feldspar, $\mathrm{Na} / \mathrm{Ca}$ aluminum silicate

Chemical analyses for major chemical species in untreated soil are tabulated in Table 4. Also included in Table 4 are results from radiochemical analyses, which indicate the absence of Cs-137, and other radionuclides identified in the 1984 report. ${ }^{2}$ It was originally planned to study the electrokinetic migration of $\mathrm{Cs}^{+}$, but that ion was no longer found in this soll. 
D.L. EISH

WSRC-RP-92-1207

September 30,1992

Page 16 of 54

Table 4. Analytical Results Based on Leach Solutions from Cuttings Soil

Analysis Method HNO $_{3}$ Leach $^{\mathrm{m}}$ Aqua Regia Leach ${ }^{b}$ Water Leach ${ }^{\mathrm{a}}$

Inorganic species

$\begin{array}{llcc}\mathrm{Ca} & \text { ICPES } & 390 \pm 30 & 469 \pm 49 \\ \mathrm{Cu} & \text { ICPES } & 1.70 \pm 0.08 \mathrm{C} & 4.99 \pm 1.64 \\ \mathrm{~Pb} & \text { ICPES } & \mathrm{BDL} & 15.7 \pm 1.04 \\ \mathrm{Ba} & \text { ICPES } & 0.67 \pm 0.32 & 8.23 \pm 0.55 \\ \mathrm{Sr} & \text { ICPES } & 0.44 \pm 0.03 & 1.84 \pm 0.23 \\ \mathrm{Cr} & \text { ICPES } & 2.81 \pm 0.24 & 14.2 \pm 0.71 \\ \mathrm{Zn} & \text { ICPES } & 27.8 \pm 3.7 & 34.8 \pm 2.9 \\ \mathrm{U} & \text { UChemCheck }^{\mathrm{TM}} & 0.61 \pm 0.14 & \text { not determined }\end{array}$

Radionuclide Analyses

$\begin{array}{llcc}\text { Cs-137 } & \gamma \text {-scan } & \text { BDL } & \text { BDL } \\ \text { other } \gamma & \gamma \text {-scan } & \text { BDI } & \text { BDL } \\ \text { gross } \alpha & \alpha \text {-count } & >50 \mathrm{~d} / \mathrm{m} / \mathrm{mL} & >50 \mathrm{~d} / \mathrm{m} / \mathrm{mL} \\ \text { gross } \beta & \text { scintillation } & \text { BDL } & \text { BDL } \\ \text { Anion Analyses } & & \end{array}$

chloride

nitrate

phosphate
a Average of 5 samples unless noted otherwise
b Triplicate samples
c Only 2 of 5 samples were above detection limit
$\mathrm{BDL}=$ below detection limits of the instrument


D.L. FISH

WSRC-RP-92-1207

September 30,1992

Page 17 of 54

The soil resistivity is calculated from Equation 1.

$$
\rho=R A \Theta / 1 \quad \text { Eq. } 1
$$

where: $\rho$ is resistivity $[\Omega-\mathrm{cm}]$

$R$ is initial resistance from $0 \mathrm{hm}^{\prime} \mathrm{s}$ Law $R=V / I$ [ $\Omega$ ]

where $V$ is the initial voltage [V]

I is the initial current [A]

$A$ is the cell cross sectional area $\left[136 \mathrm{~cm}^{2}\right.$ ]

$\Theta$ is the volumetric water content $\left[.134 \mathrm{~cm}^{3} / \mathrm{cm}^{3}\right]$

where $\theta$ is the bulk density of the soil * wt 8 water

1 is the length between electrodes. [21.5 cm]

This definition of resistivity has been modified ${ }^{27}$ to account for the cross sectional area avallable for current flow through the pore water, since it is reasonable to assume all of the current travels through the pore water in unsaturated soils. This will compensate for small differences in moisture content when comparing several soils.

The value for $R$ was determined for the split spoon soil using the apparatus and method described in section 4.2.2. It is assumed here that the cuttings soil has a resistance that is not significantly different from that found for the split spoon sample. Table 5 lists the inital voltage and current readings taken during the test. A plot of $A$ vs $V$ should describe a straight line of slope equal to $R$. That plot is shown in Figure 8 .

The average resistance of this soil is effectively $3.15 \mathrm{E}+4$ ohms. That value is comparable to resistance values obtained by Isotron ${ }^{\mathrm{TM}}$ Corp. for soll from four boreholes taken from the old TNX basin at the Savannah River Site. ${ }^{21}$ When TNX soil resistance values are corrected for the volumetric water constant, they range from $7 \mathrm{E}+3$ Ohms to $1 \mathrm{E}+4$ Ohms. The modified resistivity of the 904-A trench soil used in this test, from Equation 1 , is $2.67 \Omega-\mathrm{cm}$. 
D.L. FISH

WSRC-RP $-92-1207$

September 30, 1992

Page 18 of 54

Table 5. Initial Current and Voltage Readings for Split spoon Soil

Interval \#

Initial

Volts

1

2

4

5

6

7

8

9

10

11
0.0

2.0

4.0

6.0

8.0

10.0

12.0

14.0

16.0

18.0

20.0
Initial

Amps

4. $0 \mathrm{E}-6$

$1.0 \mathrm{E}-6$

1. $5 \mathrm{E}-4$

$2.1 E-4$

2. $7 E-4$

3. $2 \mathrm{E}-4$

$3.7 \mathrm{E}-4$

4. $4 \mathrm{E}-4$

5. $2 E-4$

$5.9 E-4$

6. $6 E-4$
$B$ calculated

$0.0 \mathrm{E}+0$

2. $0 \mathrm{E}+4$

2. $7 E+4$

2. $9 E+4$

3. $\mathrm{OE}+4$

3. $2 \mathrm{E}+4$

3. $2 \mathrm{E}+4$

3. $2 E+4$

3. $1 E+4$

3. $O E+4$

3. $O E+4$ 


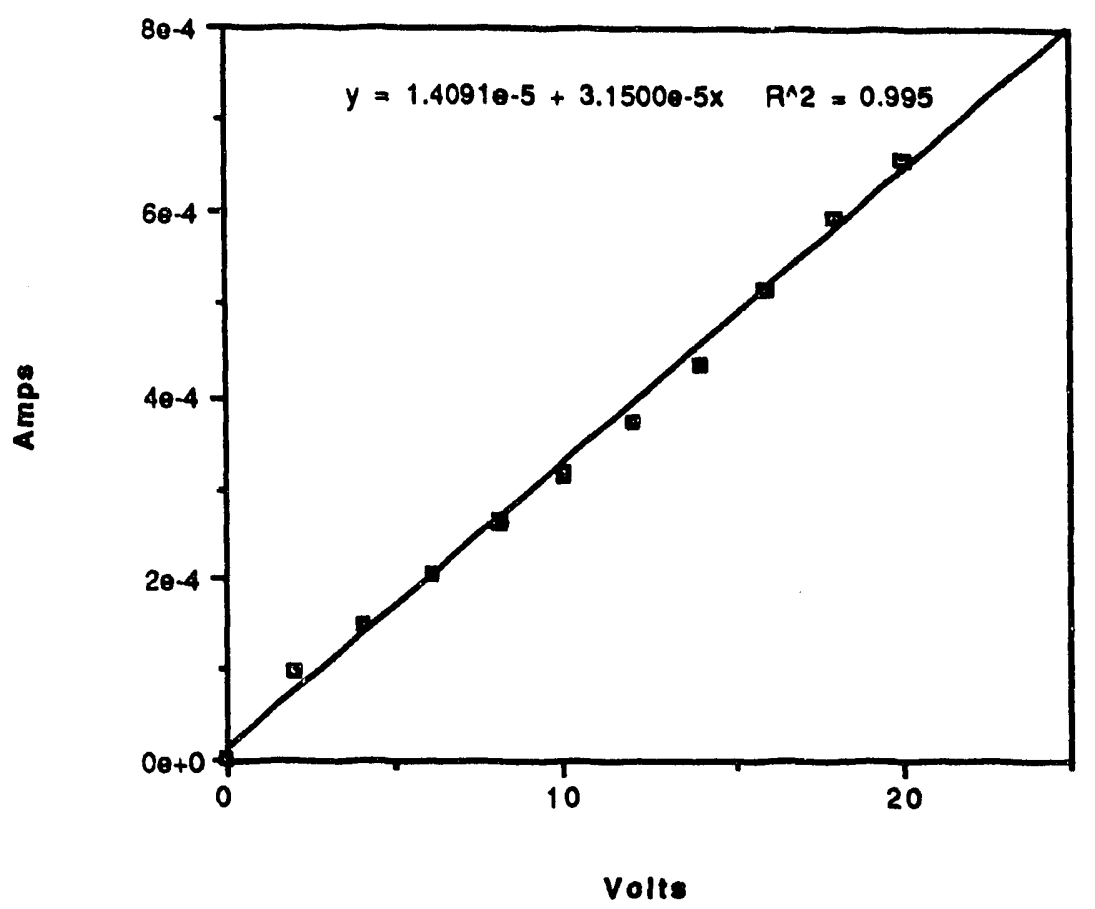

Figure 8. Resistance of split Spoon soil sample

\subsubsection{Cell Operation}

Two 1-dimensional cells containing cuttings soil were operated for a total of almost 9 days $(7.78 \mathrm{E}+5 \mathrm{sec})$. The split spoon cell flooded with acetic acid during the first hour or operation, invalidating any data from that cell. The down-time for sampling and data taking took approximately one hour each day. Both cells ran between 20 and 25 volts and steadily produced a current of 2 $\mathrm{mA}$ during that time. Table 6 compiles the daily average voltage and current during operation. 
Table 6. Cell Voltage and Current Record During Operation

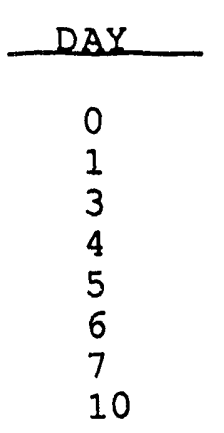

\begin{tabular}{lc}
\multicolumn{2}{c}{ Voltage } \\
\hline cell_1 & Cell_L \\
20 & 20 \\
20 & 20 \\
20 & 20 \\
22.5 & 22.5 \\
24.9 & 24.9 \\
25.2 & 25.2 \\
25.2 & 25.2 \\
25.2 & 25.2
\end{tabular}

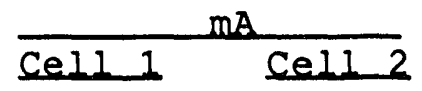

$\begin{array}{ll}7 & 7 \\ 2 & 2 \\ 2 & 2 \\ 2 & 2 \\ 2 & 2 \\ 2 & 2 \star \\ 2 & 2 \\ 2 & 2\end{array}$

* Current fluctuated between 1 and $4 \mathrm{~mA}$ over $24 \mathrm{hrs}$. but held mostly at $2 \mathrm{~mA}$. Problem was traced to a poor connection.

Typically, the current density is determined by dividing the current by the cross sectional area of the cell. For this experiment, this results in a cell current density of $1.5 E-2$ $\mathrm{mA} / \mathrm{cm}^{2}$. As noted earlier, however, it is more reasonable to assume that all of the current travels through the pore water, suggesting a more appropriate way of defining current density, especially in unsaturated soils. The pore water current density is the cell current density divided by $\boldsymbol{\theta}$, the volumetric water content of the soll. For this system, the pore water current density was $0.11 \mathrm{~mA} / \mathrm{cm}^{2}$.

\subsubsection{Soil Analyses After Treatment}

The ISOLOCK ${ }^{\mathrm{m}}$ polymer was able to effectively mimimize the expected $\mathrm{pH}$ excursions at the electrodes. By providing a medium to hold chemicals, the polymer allowed the cao circulating at the anode to react with hydrogen ion produced there from the electrolysis of water. Similarly, acetic acid circulating through the polymer at the cathode was able to neutralize the hydroxide ion formed there. The $\mathrm{pH}$ of the moist soil, as measured with $\mathrm{pH}$ indicator paper, remained near 6 for soil in all sections of the cells. It is 
evident from Table 7 that transport of water from the anode to the cathode is very small, indicating that electroosmosis effects are small compared to those of electromigration for the movement of ions.

Table 7. $\mathrm{pH}$ and Water Content of Cuttings Soil After Treatment wt $\& \mathrm{H}_{2} \mathrm{O}$ by Section

Operation Time, days

0
3
4
5
6
7
10

Cell 1 Cathode Middle Anode

10.3
14.4
14.0
13.9
14.4
13.7
13.8

10.3

11.8

12.7

13.0

13.3

12.0

12.8
10.3

12.0

12.5

12.9

13.4

12.7

12.1
Cell 2

Cathode Middle Anode

10.3
13.0
13.1
13.6
13.6
14.6
13.7

10.3

$10.3 \quad 10.3$

$10.3 \quad 10.1$

$11.0 \quad 11.5$

$12.4 \quad 12.2$

$\begin{array}{ll}12.6 & 13.7\end{array}$

$11.8 \quad 11.8$

$\begin{array}{ll}9.8 & 10.8\end{array}$

Results from leaching anode, cathode, and soil sections in $16 \mathrm{M}$ $\mathrm{HNO}_{3}$ after treatment with the current showed some migration of the ions. The concentrations in the soil of ions of interest, noted in Table 4, are shown in Figures $9-15$ below. Tables $8-23$, found in Appendix 2, contain the data from which the graphs were made. Calcium ion is not graphed because the concentration of $\mathrm{Ca}^{2+}$ remained essentially constant throughout the experiment, as it should have. Calcium ion was continually being introduced from the $\mathrm{pH}$ regulating solution at the anode to retain charge balance for the system. Thus, although calcium ion does migrate to the cathode, it exhibited an essentially constant concentration in the soil because it was being added at the anode.

A barium ion cell profile is shown in Figure 9. $\mathrm{Ba}^{2+}$ represents a typical alkaline earth ion and its behavior, in the absence of $\mathrm{pH}$ excursions in the cell, should not be significantly different from that of other alkaline earth metals. All data in the graphs represent $\mathrm{HNO}_{3}$ leaches. Aqua regia leaches always found higher ion concentrations in the untreated soil (see Table 4). 
CELl 1 Ba PROfile

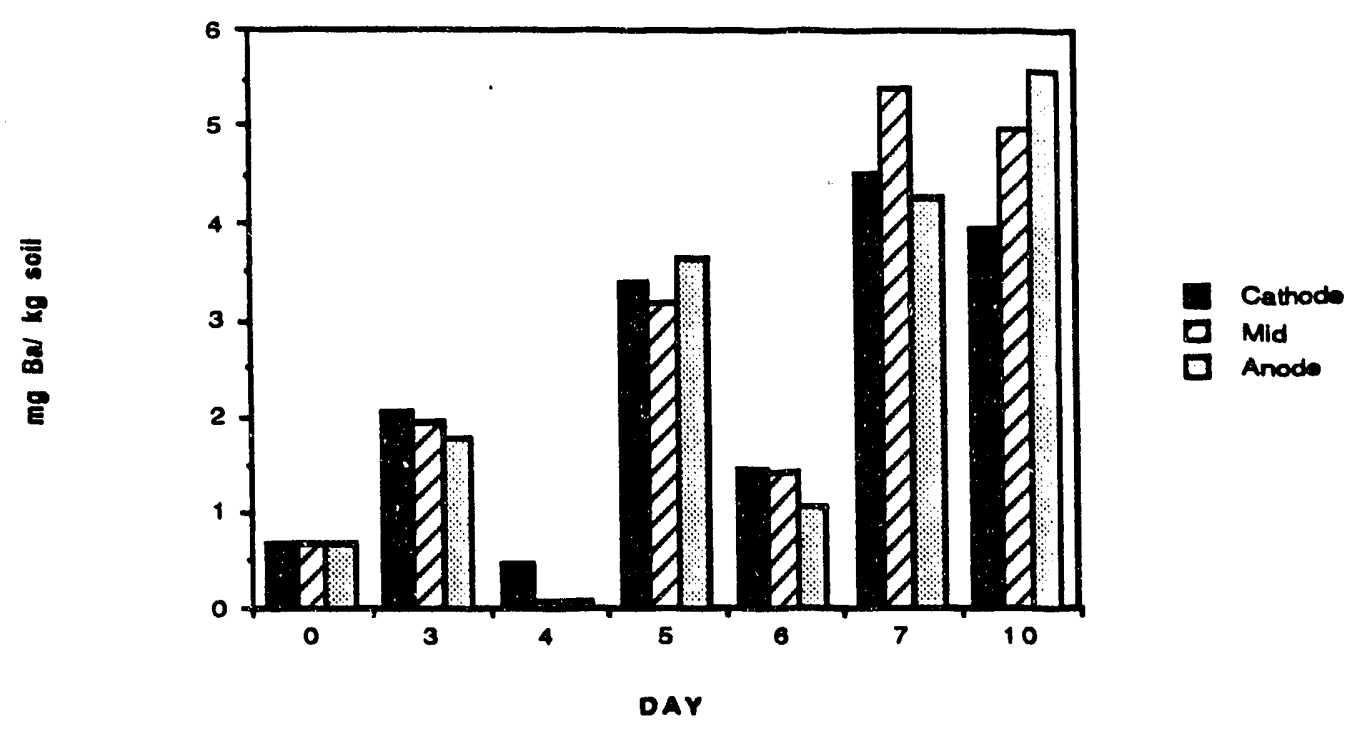

CELL 2 Ba PRofile

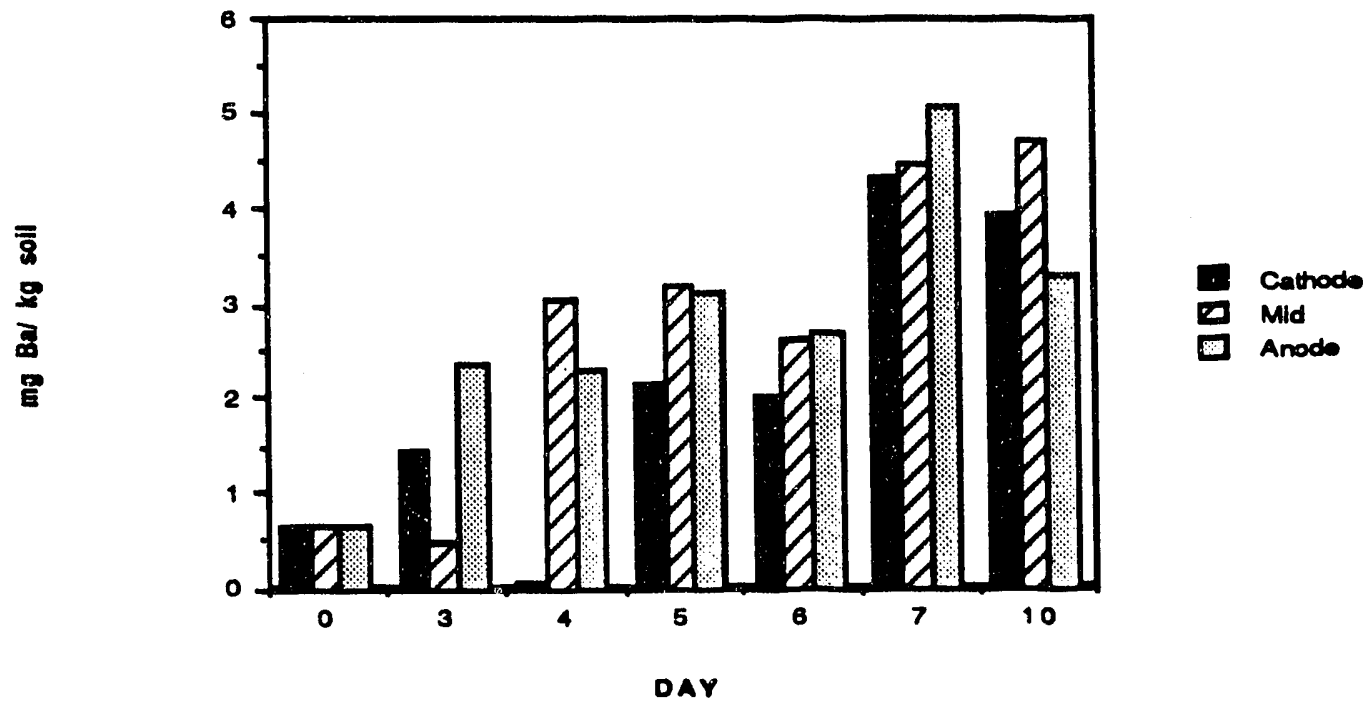

Figure 9. Barium Ion Soll Profiles 
Other $\mathrm{M}^{2+}$ ions were observed. Of these, $\mathrm{Sr}^{2+}$ should, and does, exibit behavior similar to that of $\mathrm{Ba}^{2+}$. The $\mathrm{Sr}^{2+}$ soil profile is found in Figure 10. Three transition metal ions, $\mathrm{Cu}^{2+}, \mathrm{Pb}^{2+}$, and $\mathrm{Zn}^{2+}$ were also checked. Their concentrations in the soil after treatment in an electric field are shown in Figures 11-13, respectively.

Chromium was probably introduced from the spill to the soil as $\mathrm{CrO}_{4}{ }^{-2}$. During this test, the chromium was found to be migrating toward the cathode, indicating that it was $\mathrm{Cr}^{3+}$ that was responding to electrokinetic migration. (Figure 14) Aqua regia leach results from soil taken after 10 days of operation closely agree with nitric acid leach results for the same soil for most metals, indicating that those metal ions had become more accessible to the leaching solution.

Data indicate that uranium showed little evidence of migration until the sixth day of treatment (Figure 15).

Analysis of dissolved, weighed fractions of the polymers from each electrode and of the resin found in the cathode polymer located the metals of interest (except $U$, which could not be analyzed in aqua regia) at the cathode. Aqua regia leaching was conducted on weighed pieces of each metal electrode, to dissolve any metals that might have plated out on the electrode. The leached solutions also indicated that the migration of metal ions from the soil to the cathode occurred. Unfortunately, the mild steel cathode contained $8 \% \mathrm{Cr}$, making it difficult to quantify the amount of $\mathrm{Cr}$ from the soil in that leachate. These data are contained in Table 22 .

Table 22. Composition of Electrode Assembly Aqua Regia Leachates

$\begin{array}{cllccc}\text { Metal } & \begin{array}{l}\mathrm{mg} \text { Metal/g Polymer } \\ \text { Cathode }\end{array} & \begin{array}{c}\mathrm{mg} \text { Metal/g } \\ \text { Anode }\end{array} & \begin{array}{c}\mathrm{mg} \text { Metal/g Electrode } \\ \text { Cathode Resin } \\ \text { Cathode }\end{array} & \begin{array}{c}\text { Elede } \\ \text { Anode }\end{array} \\ \mathrm{Ba} & 0.007 & 0.00 & 0.016 & 0.009 & 0.00 \\ \mathrm{Sr} & 0.006 & 0.00 & 0.020 & 0.003 & 0.00 \\ \mathrm{Cu} & 0.017 & 0.00 & 0.024 & 0.56 & 0.00 \\ \mathrm{Zn} & 0.54 & 0.16 & 1.8 & 0.51 & 0.026 \\ \mathrm{Cr} & 0.02 & 0.00 & 0.031 & 0.213 & 0.00\end{array}$


Cell 1 St profile

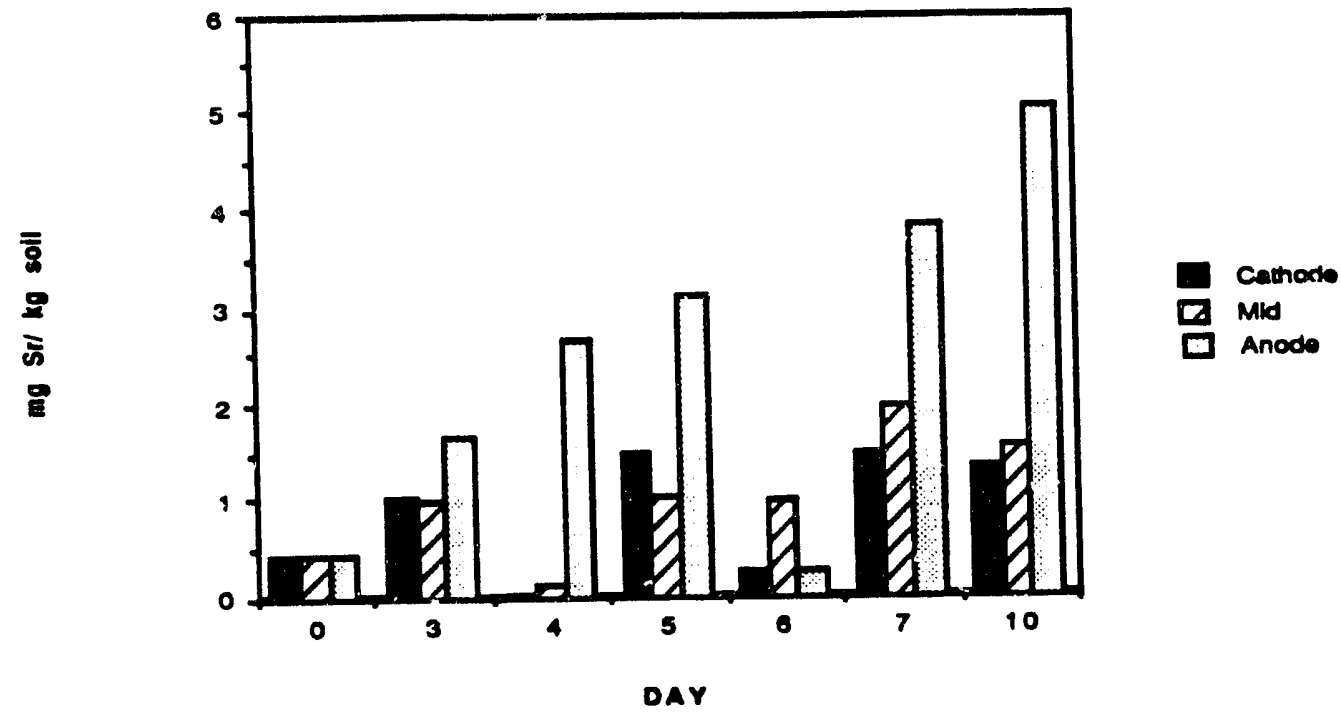

Cell 2 sr profile

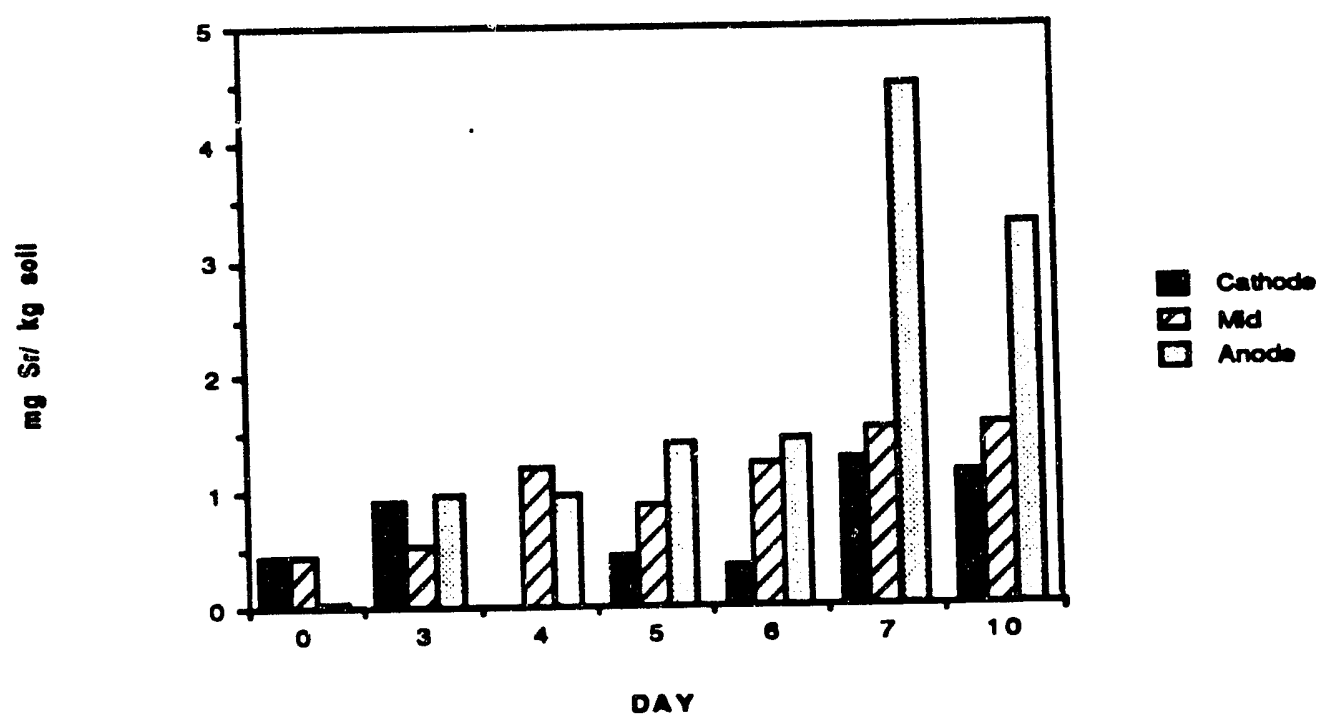

Figure 10. Strontium Ion soil Profiles 


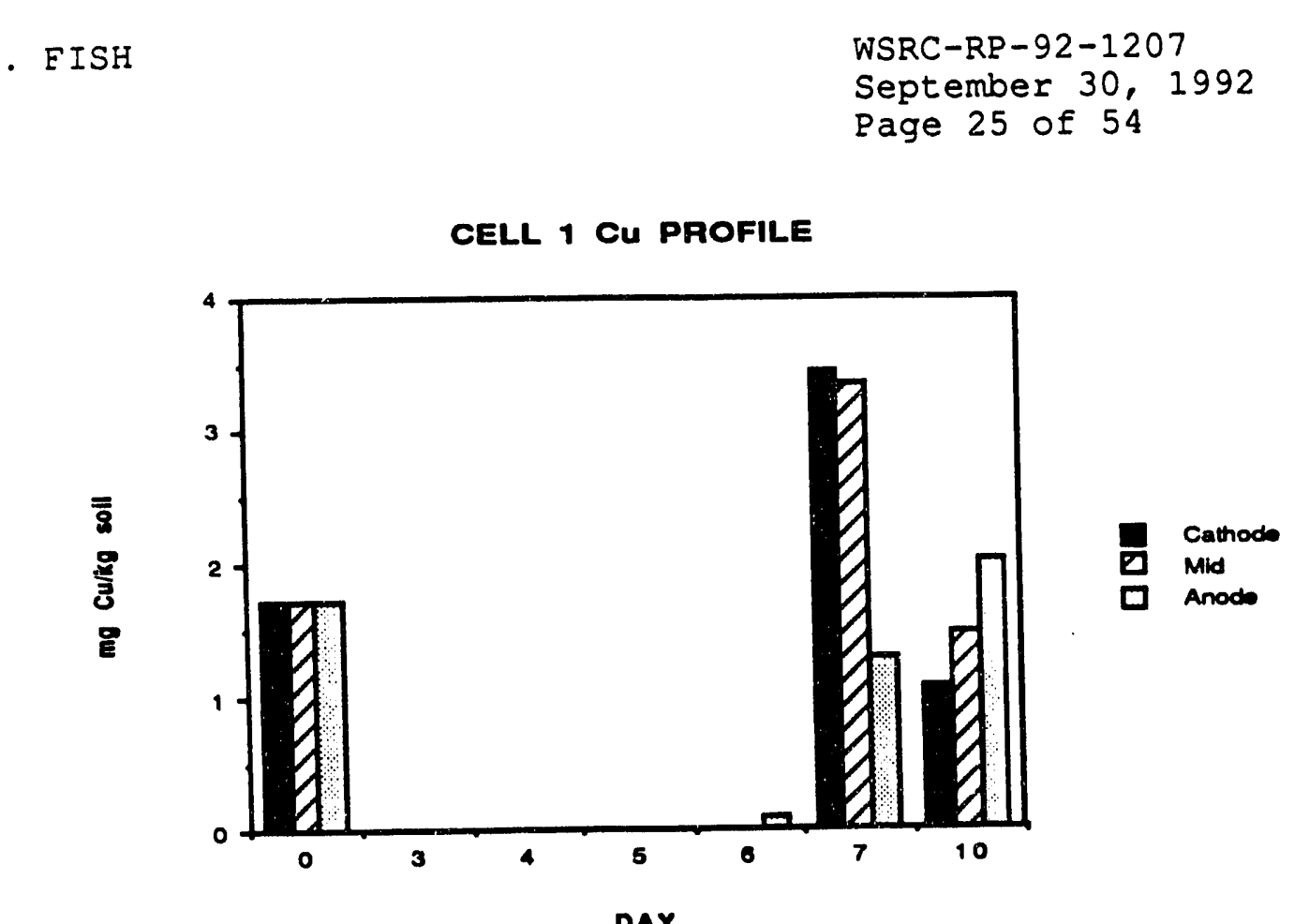<smiles>C1=[Si]C=[Si]=1</smiles> 
D.I. EISH

WSRC-RP-92-1207

September 30, 1992

Page 26 of 54

cell 1 pb paofile

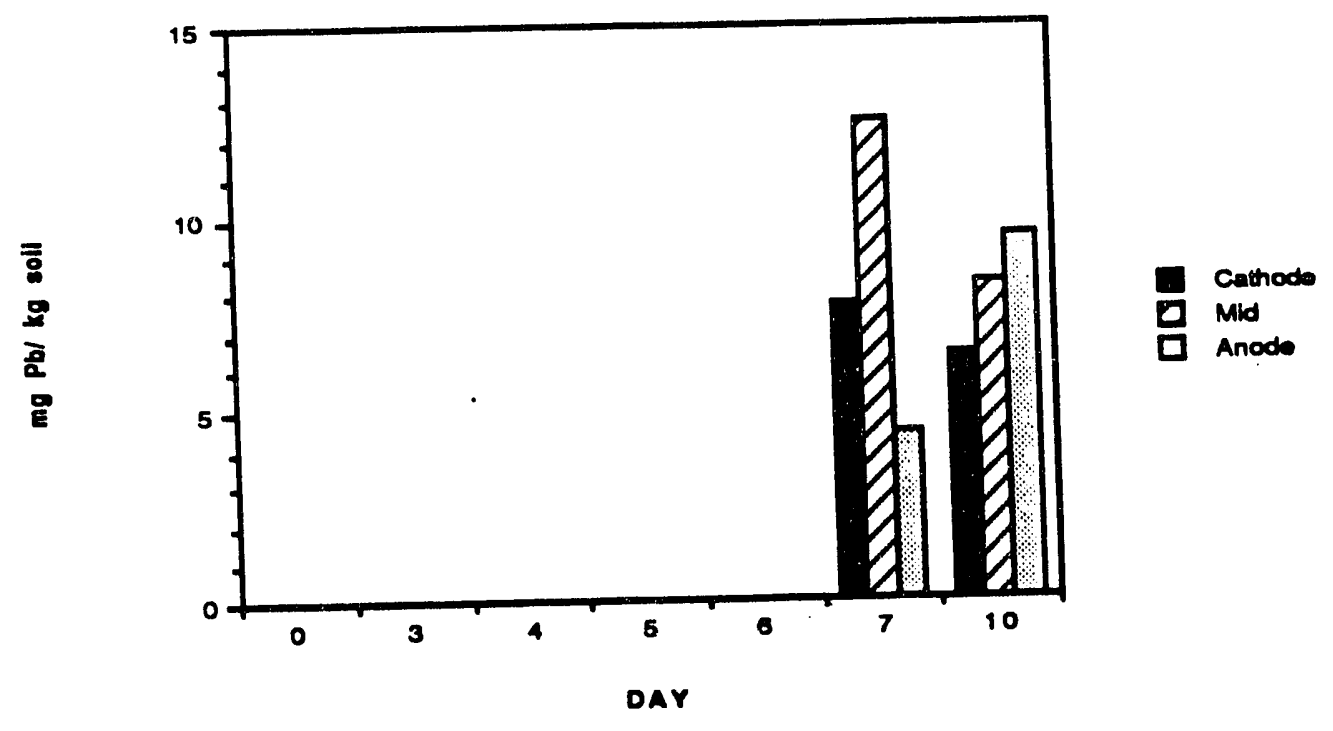

CELL 2 Pb PROFile

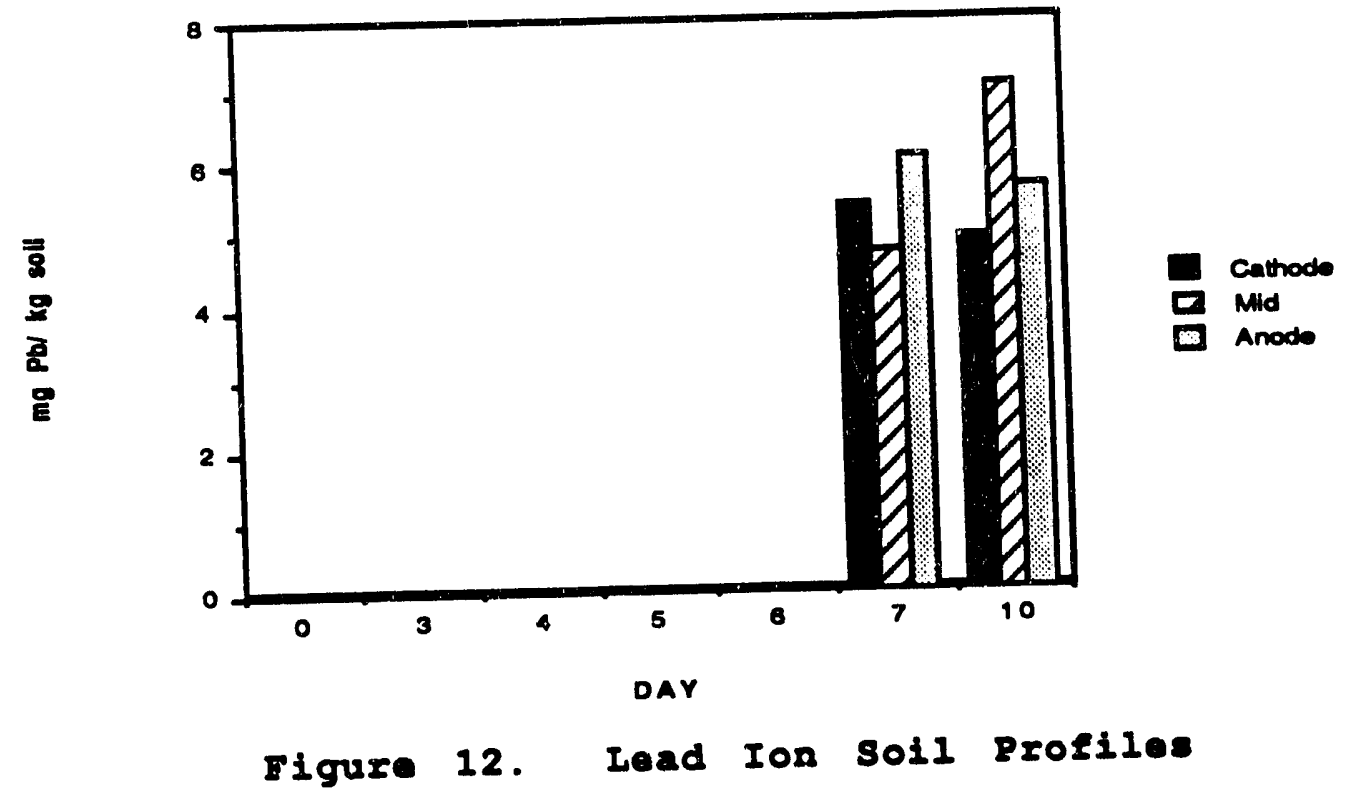


D.L. FISH

WSRC-RP - 92-1207

September 30, 1992

Page 27 of 54

Cell 1 Zn profile

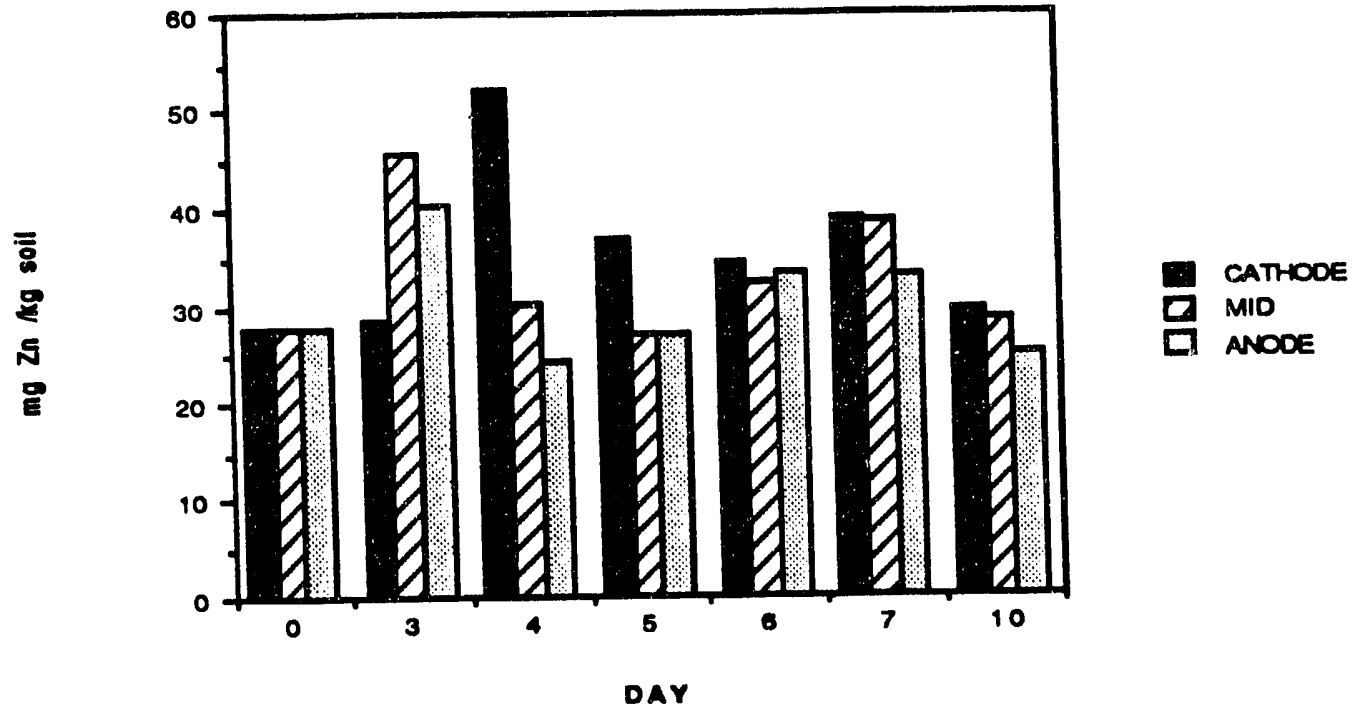

CELL 2 Zn PROfIL.E

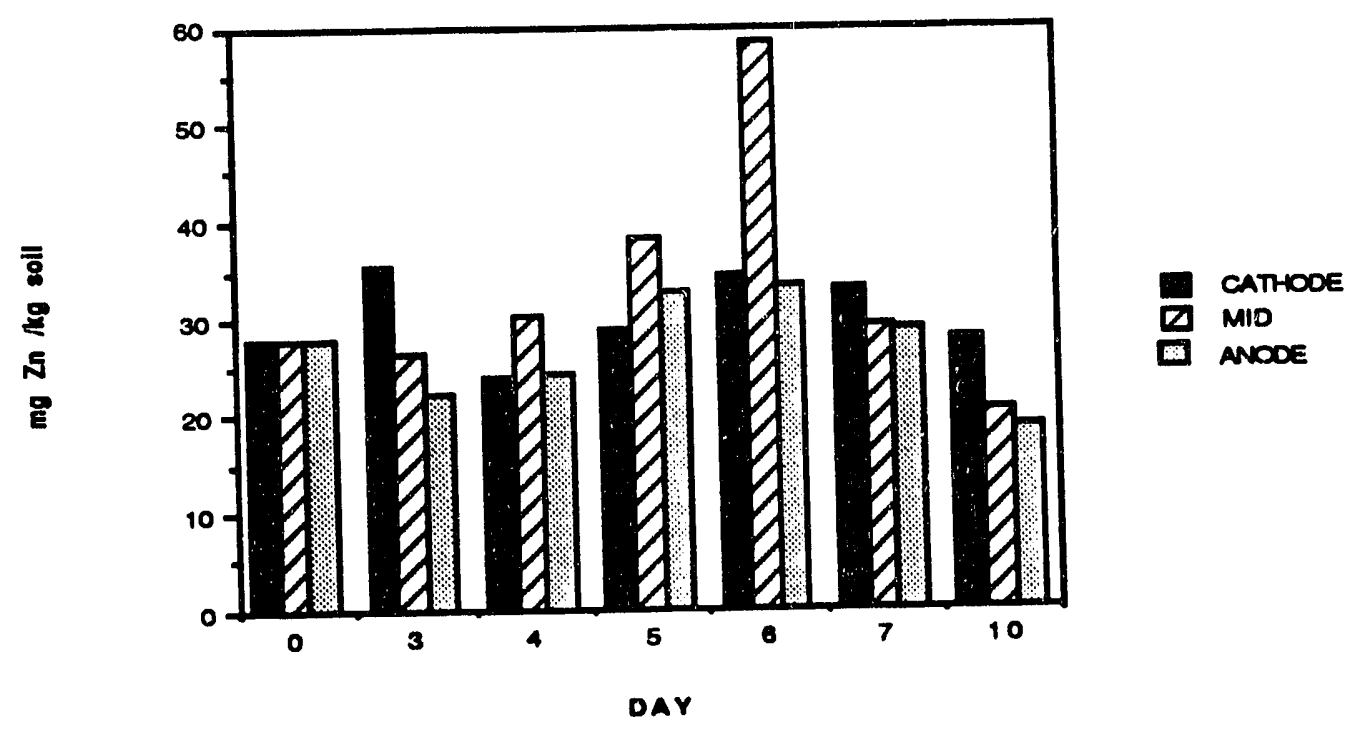

Figure 13. Zinc Ion soil Profile 
cell $1 \mathrm{Cr}$ profile

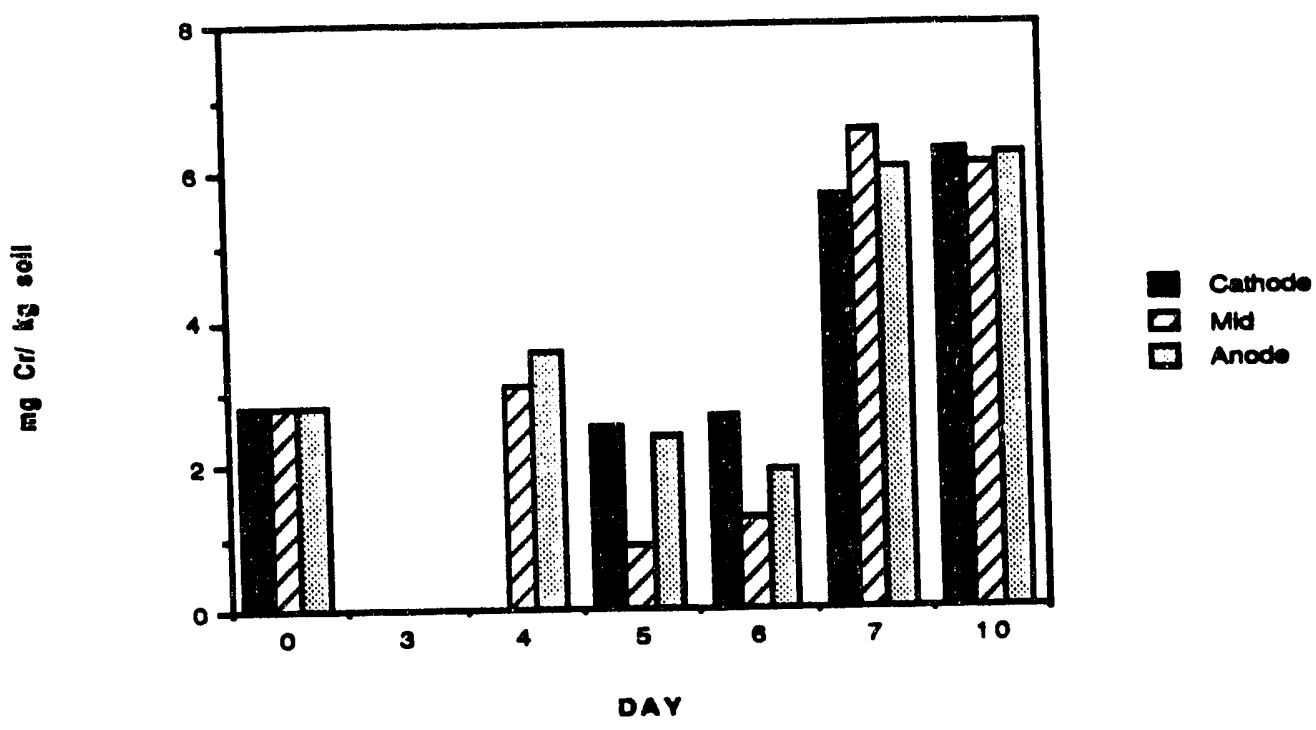

Cell 2 Cr profile

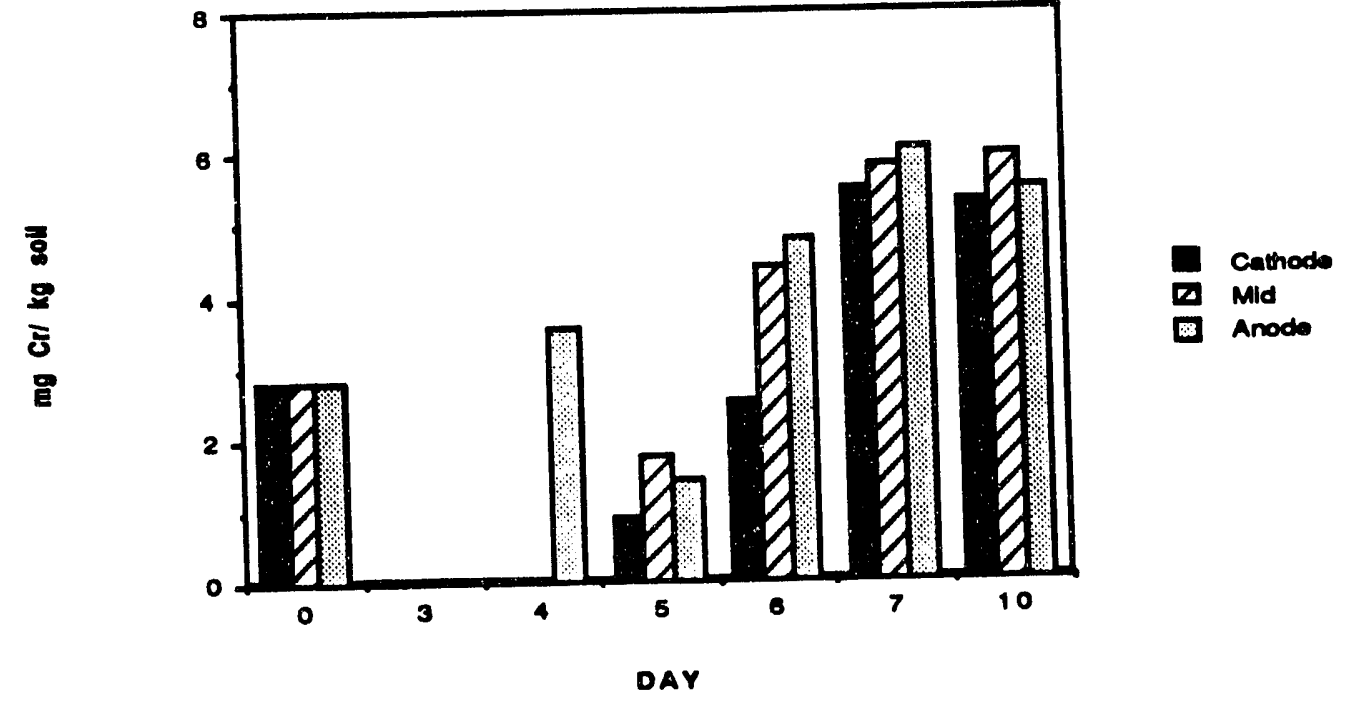

Figure 14. Chromium Ion soll Profile 
Cell 1 U PRofile

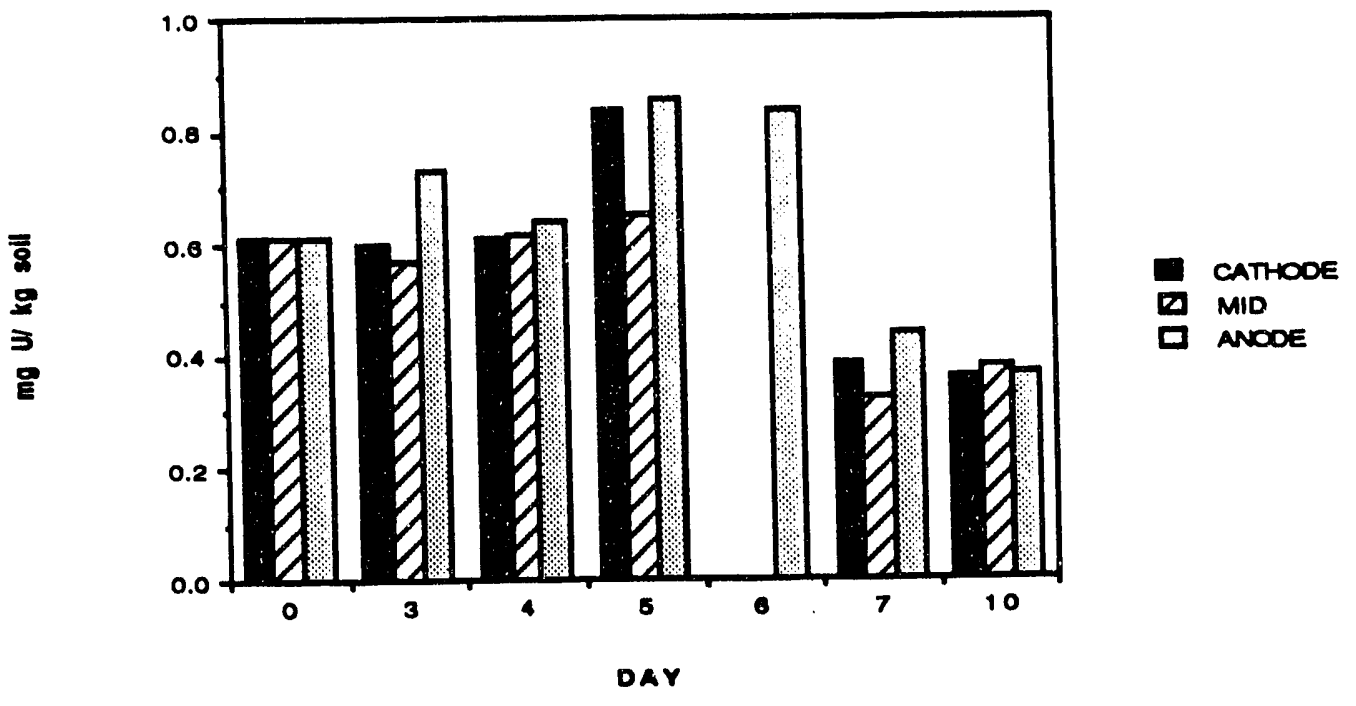

Cell 2 u profile

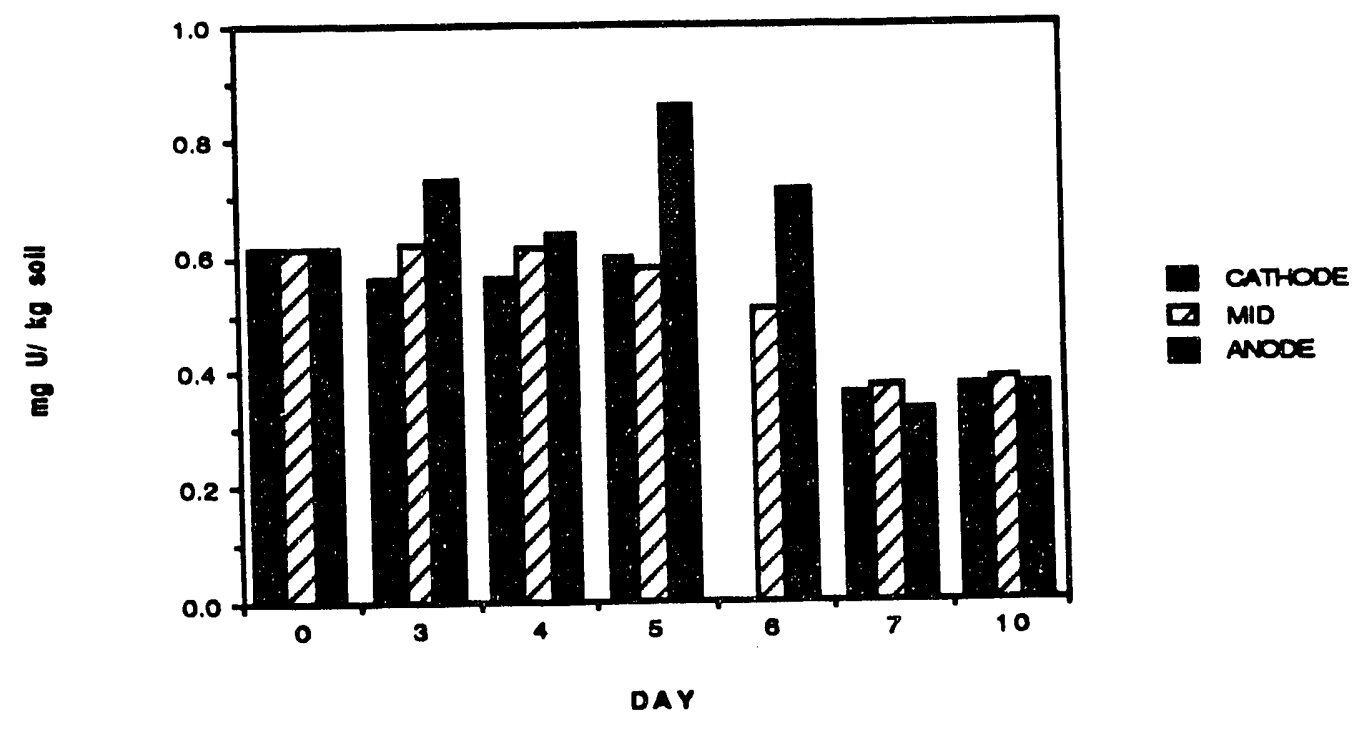

Figure 15. Uranium Ion Soil Profile 


\subsection{DISCUSSION}

Data for the 1-dimensional cell electrokinetic migration studies done in this work are for the cuttings soil. The original intent of the study was to perform the cell test using soil from the split spoon. Flooding of the cell containing the split spoon sample precluded the use of that soil for experimentation. Results of the soil characterization studies that were done on split spoon soll are presumed to be valid for the cuttings soils that were ultimately used for the cell tests. In discussing leach tests, however, it is important to differentiate between split spoon and cuttings solls. The concentrations of tons leached from the soils are greater in the split spoon sample because auger cuttings were not present to dilute the soil. Therefore, comparisons are made throughout this report between concentrations for cuttings soils and not between cuttings soils and split spoon soil.

This study shows that leaching of soils is an area that needs further research. Five samples were submitted for each analysis because of the imprecision in analytical results. This imprecision is attributed to sample variability and not to the analyses themselves. The leaching solution was also important. Concentrations of ions in $16 \mathrm{M} \mathrm{HNO}_{3}$ leachates were significantly less than those in aqua regia leachates and significantly greater than in acetic acid leachates. It is apparent that a specific fraction of all the ions sorbed on the soil is more difficult to leach than the bulk of those ions. This may be because the moredifficult-to-leach fraction is trapped in the pores of the soil, rather than on the surface of soil particles, and must first diffuse to the leachate. A study is underway in our laboratory to devise a leaching procedure that gives consistent and accurate results with SRS soils.

Electrokinetic migration technology has been demonstrated in this work to be capable of causing cations to migrate to the cathode. Using the ISOLOCK ${ }^{\mathrm{TM}}$ polymer, which serves for $\mathrm{pH}$ regulation as well as trapping of the mobllized ions, the lons can be removed from the soil system in a solid matrix with the expenditure of a very small amount of electricity. Regulation of the pH at the electrodes eliminates $\mathrm{pH}$ excursions in the soil that can cause precipitation in the soil or formation of soluble complexes that cannot be removed from the system. Mass balance has not been established quantitatively in this study because the polymer did 
not appear to sorb and trap the ions uniformly in its matrix. That very matrix also interfered with calculations for mass balance because fillers used in the polymer were found to contain small amounts of zinc and lead ions, two of the ions being studied.

Although current density during the 10-day test was constant, the graphs in Figures 9-14 show that migration of the ions through the soil was not constant. Surges of ion movement are evident. A rationale for this behavior is that ions sorbed on the surface are displaced easily under the influence of the current. These migrate immediately to the electrode. Ions trapped inside the pores of the soil must first diffuse out of the soil before they can migrate. Increased concentration in the treated soil due to diffusion from the pores appears at day 6 in the graphic profiles of all ions studied. The diffusion step is the slow step of the process. Once liberated, however, the ions then migrate in a second "wave" through the soil toward the appropriate electrode, where they are captured. This behavior agrees with behavior of the soil in leaching tests. Weak or dilute acid solutions leach a small fraction of the ions from the soil compared to more concentrated acids. Often, the ion concentrations in portions of treated soil are found to be much higher than in untreated soil. It is believed that this is due to the fact that ions that were originally in the soil pores have been released by the action of the current and are more easily leached. Since electrokinetic migration technology appears to be able to remove ions trapped in the pores of the soil, development of a rigorous leaching procedure is important if mass balance is ever to be achieved for the process. An aqua regia leach of treated solls on days 3-6 of operation would probably have identifled measurable concentrations of all ions of interest, whereas the concentrations of lead and copper ions, for example, in the same soils were below detection limit $(30 \mu \mathrm{g} / \mathrm{mL})$ in a nitric acid leachate.

It might be argued that the introduction of acetate ions to the soil from the cathode chamber could solubilize metals sorbed on the soil through the formation of complex ions. This process could also explain the ion distributions observed in the soil during treatment. However, studies with this soil showed that acetic acid could not effectively leach anything from the soil except lead and zinc ions, and then only in very small concentrations. Other complexants might assist the solubilization of metals during the operation of a cell, but acetate complexation is not considered an important factor here. 
In this test, it is apparent that chromium was ultimately present

as $\mathrm{Cr}^{3+}$. If it was introduced to the soll as $\mathrm{CrO}_{4}^{-2}$, as expected, it may have been reduced in situ by microorganisms before this test began. Reduction to $\mathrm{Cr}^{3+}$ could explain low concentrations in dilute acid leachates; the kinetics of dissolution are very slow for $\mathrm{Cr}^{3+}$. Lindgren, et. al. have observed ${ }^{2}$ the electrokinetic migration of chromate ion in sand ( 10 wt 8 water) to the anode after 22 hours of treatment. They noted that the total chromium content in the sand near the anode at the end of the experiment was significantly less than the amount of chromium added initialiy, and postulate that most of the Cr(VI) might somehow have been reduced and precipitated as Cr(III). For longer operating times, such as were employed in this test, any $\mathrm{Cr}^{3+}$ would migrate to the cathode.

If the $\mathrm{Cr}$ in the aqua regia leach (Table 4) is considered the total chromium in the soil, each $3.5 \mathrm{~kg}$ cell contained $49.7 \mathrm{mg} \mathrm{Cr}$. After 10 days of operation, leach results for the three portions of each cell's soil bed, when totaled, indicate that 63-65\% of the Cr had been removed from the soll.

\subsection{CONCLUSIONS}

- This study shows that electrokinetic migration technology, using the Isotron ${ }^{\mathrm{TM}} /$ ISOLOCK $^{\mathrm{TM}}$ approach, will be effective for an in situ treatment of soll adjacent to the 904-A trench for the removal of any metal ion contaminants.

- Electromigration of metal ion contaminents found in duplicate $3.5 \mathrm{~kg}$ samples of soll taken from the 904-A trench area at SRTC has been demonstrated in a 1-dimensional experiment. The migration of chromium, lead, zinc, copper, and uranium ions was monitored daily during a 10-day test at 20-25 $\mathrm{V}$ and $2 \mathrm{~mA}$. At the end of the test, $65 \%$ of the $\mathrm{Cr}$ had been removed from the soil; 57\% of the uranium was removed.

- Metal cations migrated to the cathode where they were removed from the soil and trapped in a solid matrix of ISOLOCK ${ }^{\mathrm{TM}}$ polymer and the GT-73 cation exchange resin beads that were incorporated in the polymer. The electrodes were imbedded in the polymer. 
- Electromigration techniques appear to effect the release of ions that are so tightly bound to the soil that they are difficult to leach from the soil. This behavior indicates the need for development of special leaching techniques, possibly soil digestion techniques, that will accurately reflect the total concentration of ions in the soll.

- Although the low current density induced migration of ions through the soil bed, it did not appear to destroy or degrade the soil. Sodium, aluminum, and sllicon concentrations were monitored throughout the progress of the test. Concentrations of these species in the leachates did not change, indicating that clay in the soil had maintained its integrity. Iron, from amorphous iron oxy/hydroxides found in the soil, was captured by the polymer surrounding the cathode, however.

- Regulation of the $\mathrm{pH}$ at each electrode with chemicals was effective and was important in the prevention of precipitation or complex formation by the ions in the soil bed.

- Uranyl ion will require more time to effect removal from this soil, compared to time required for simple $\mathrm{M}^{2+}$ ions, due to its lower mobility.

\subsection{QUALITY ASSURANCE}

Data generated in this study is recorded in WSRC-NB-92-231 and WSRC-NB-92-259. Reagent grade chemicals were used in leaching. Analyses were performed by the SRTC Analytical Development Section following methods developed for "routine customer assisted" analysis.22 Standard addition methods were used to check uranium analyses. IC, ICPES, and radioactive counting analyses were monitored using blanks and standards traceable to the National Bureau of Standards.

\subsection{RERERENCES}

1. HILAND, D.E., "904-A Trench Soil Analysis Program", presentation to C.A. SMITH, Dec. 21, 1984.

2. LINDGREN, E.R., MATTSON, E.D., AND KOZAK, M.W., "Electrokinetic Remediation of Contaminated Soils: An Update", Proceedings of 
D.I. FISH

WSRC-RP-92-1207

Septemoer 30,1992

Page 34 of 54

Waste Management '92, Tucson, Az, pp 1309-1314.

3. OVERBEEK, J.T.G. and BIJSTERBOSCH, Electrokinetic Separation Methods, Righetti, Van Oss, and Van der Hoff, eds., Elsevier Press, 1979 .

4. CASAGRANDE, L., Geotechnique, 1, 1959, 1949.

5. HUNTER,R.L., Zeta Potential in Colloid Science, Academic Press, New York, New York, 1981.

6. SPRUTE, R.H. and KEISCH, D.J., "Bureau of Mines Report of Investigations", R18441, U.S. Department of the Interior, 1982.

7. SPRUTE, R.H. and KELSCH, D.J., "Bureau of Mines Report of Investigations", R18666, U.S. Department of the Interior, 1982.

8. LOCKHART, N.C., Colloids and surfaces, 6, 239, 1983.

9. SUNDERLAND, J.G., Applied Electrochemistry, 17, 889, 1987.

10. SEGALL, B.A., O'BANNON, C.E., and MATTHIAS, J.A., J.Geotech Engineering Division ASCE, 106, No. GT10, 1148-1153, 1980.

11. RENAUD, P.C. and PROBSTEIN, R.F., Bbysico-Chemical Hydrodynamies, 9, 345, 1987.

12. SHAPIRO, A.P., RENAUD, P.C. and PROBSTEIN, R.F., PhysicoChemical Hydrodynamics, 11,785-802, 1989.

13. ACAR, Y.B., GALE, R.W., PUTMAN, G., and HAMED, J., "Electrochemical Processing of Solis; Its Potential Use in Environmental Geotechnology and Significance of $\mathrm{pH}$ Gradients", Second International Symposium on Environmental Geotechnology", Shanghai, China, May 1989.

14. HAMED, J., ACAR, Y.B., and GALE, R.W., I.Geotechnical Engineering Division ASCE, 1989.

15. RUNNELS, D.D. and LARSON, J.L., Ground Water Monitering Beview, 6, 3, 85-88, 1986.

16. LAGERMAN, R.,"Chemistry and Industry, September 18,1989.

17. DAHAB, M.F., KELLY, W.E., and GODERYA, F., "Removal of 
Metallic Contaminants in Unsaturated Soils Using Electrokinetics", presented at Electrokinetics Workshop, Atlanta, Georgia, January $22-23,1992$.

18. BANNERJEE, S., "In-Situ Remediation by Electrokinetic Transport", presented at Electrokinetics Workshop, At lanta, Georgia, January 22-23, 1992.

19. GRAVES, R., "Uranium Removal at Bruni, Texas", presented at Electrokinetics Workshop, Atlanta, Georgia, January 22-23, 1992.

20.TRIAY, I., MILLER, G., and MITCHELL, A., "Electrochemical Removal of Actinides", presented at Electrokinetics Workshop, Atlanta, Georgia, January 22-23, 1992.

21. CONDON, M.C., private communication, 1992.

22. "Guide to Savannah River Laboratory Analytical Services Group (U)", WSRC-IM-90-23, Section C, "Analytical Methods".

23. Handbook of Chemistry and Physics, CRC Press, Cleveland, Ohio, 
D.I. FISH

WSRC-RP-92-1207

September 30, 1992

Page 36 of 54

APPENDIX 1

Field Geologic Log for Borehole SBA-1 
FIELD GEOLOGIC LOG

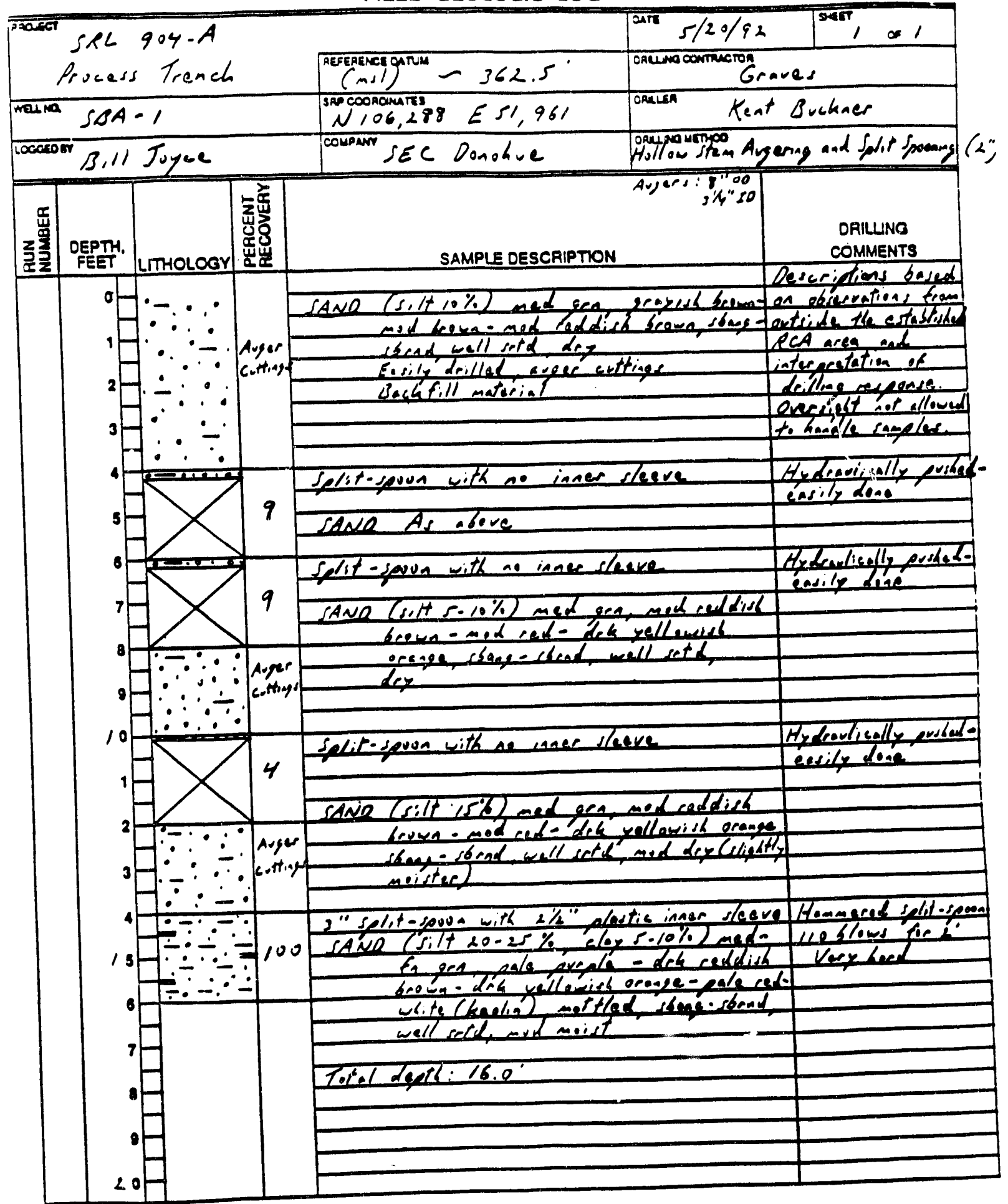


APPENDIX 2

Table 8. Cell 1 Ca Concentrations $(\mathrm{mg} / \mathrm{kg})$ in Soll Sections After Treatment.......................... 39

Table 9. Cell 2 Ca Concentrations $(\mathrm{mg} / \mathrm{kg}$ ) in Soil Sections After Treatment....................40

Table 10. Cell 1 Cu Concentrations (mg/kg) in Soll Sections After Treatment......................41

Table 11. Cell $2 \mathrm{Cu}$ Concentrations $(\mathrm{mg} / \mathrm{kg})$ in Soil Sections After Treatment....................42

Table 12. Cell $1 \mathrm{~Pb}$ Concentrations $(\mathrm{mg} / \mathrm{kg}$. in Soll Sections After Treatme:at.....................43

Table 13. Cell $2 \mathrm{~Pb}$ Concentrations $(\mathrm{mg} / \mathrm{kg})$ in Soil Sections After Treatment......................44

Table 14. Cell $1 \mathrm{Ba}$ Concentrations (mg/kg) in soll Sections After Treatment......................45

Table 15. Cell 2 Ba Concentrations (mg/kg) 1. Soll Sections After Treatment....................46

Table 16. Cell $1 \mathrm{Sr}$ Concentrations (mg/kg) in Soil Sections After Treatment.....................47

Table 17. Cell $2 \mathrm{Sr}$ Concentrations $(\mathrm{mg} / \mathrm{kg})$ in Soll Sections After Treatment...................... 8

Table 18. Cell $1 \mathrm{Cr}$ Concentrations $(\mathrm{mg} / \mathrm{kg})$ in Soil Sections After Treatment......................49

Table 19. Cell $2 \mathrm{Cr}$ Concentrations $(\mathrm{mg} / \mathrm{kg})$ in Soll Sections After Treatment....................... 50

Table 20. Cell $1 \mathrm{zn}$ Concentrations $(\mathrm{mg} / \mathrm{kg}$ ) in Soll

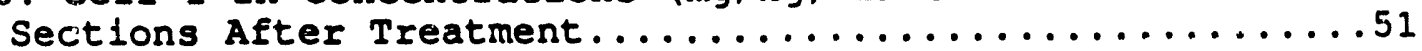

Table 21. Cell $2 \mathrm{zn}$ Concentrations $(\mathrm{ng} / \mathrm{kg})$ in Soll Sections After Treatment.................... 52

Table 22. Cell 1 U Concentrations (mg/ $\mathrm{kg}$ ) in Soll Sections After Treatment.....................53

Table 23. Cell 2 U Concentrations $(\mathrm{mg} / \mathrm{kg})$ in Soil Sections After Treatment..................... 54 


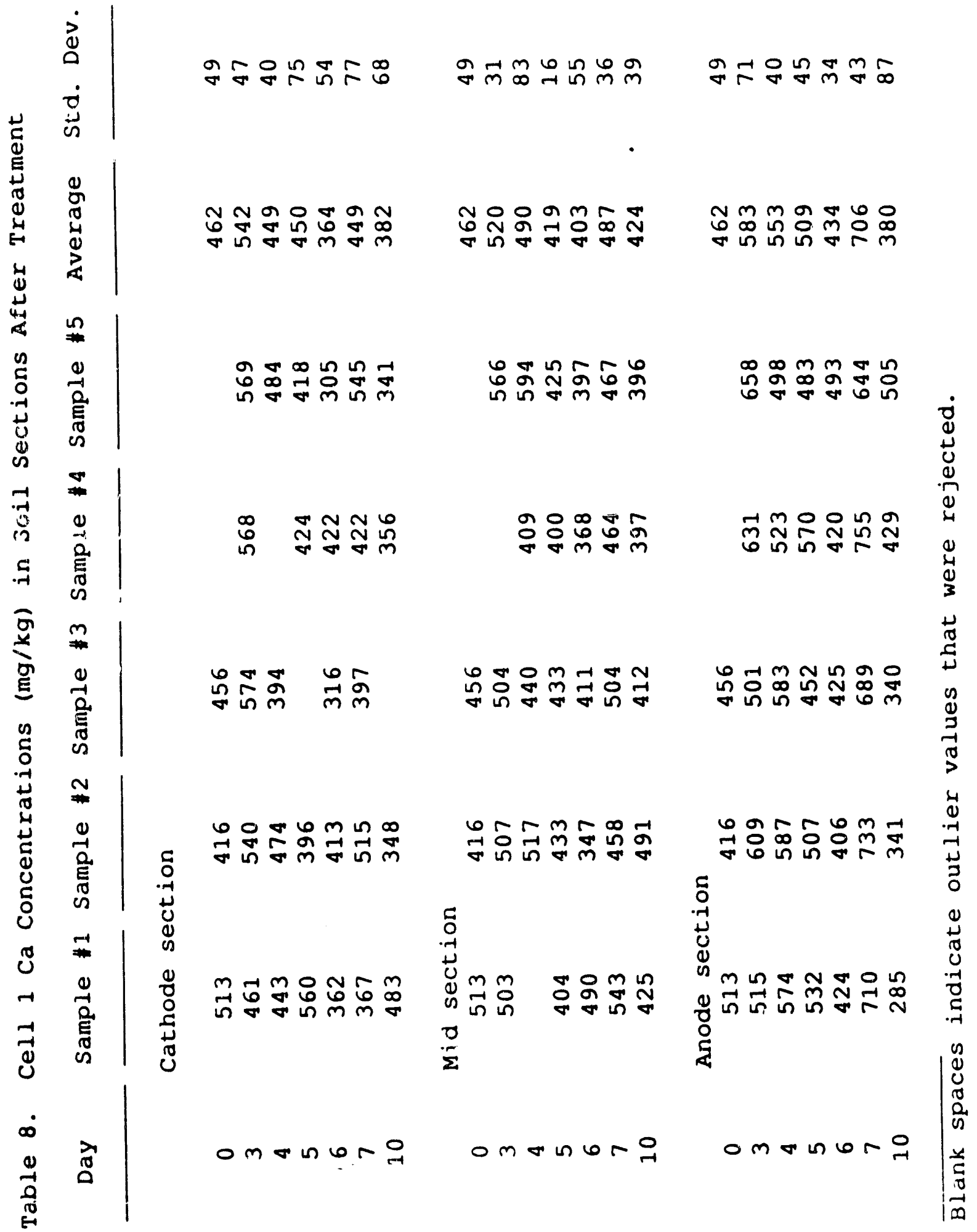




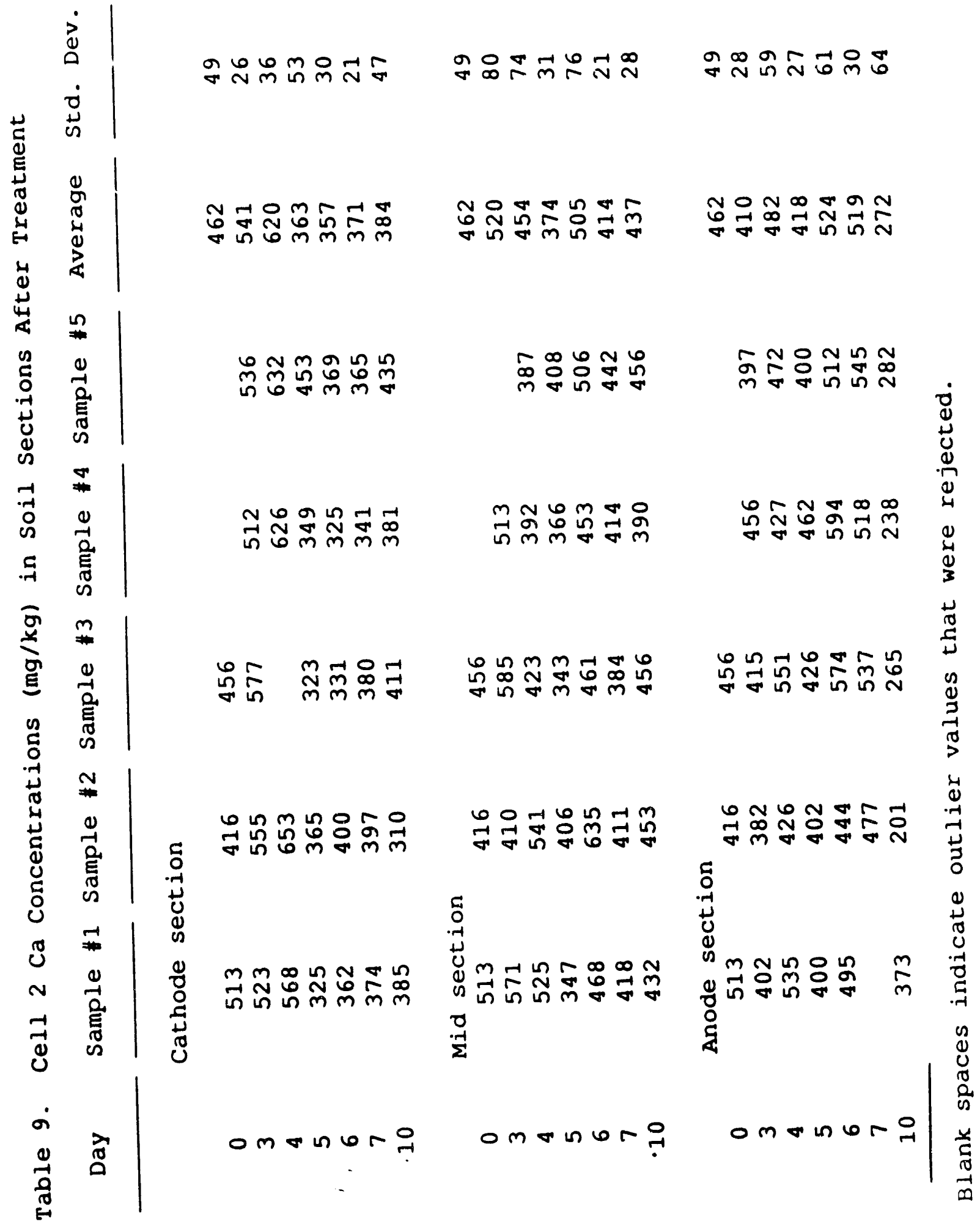




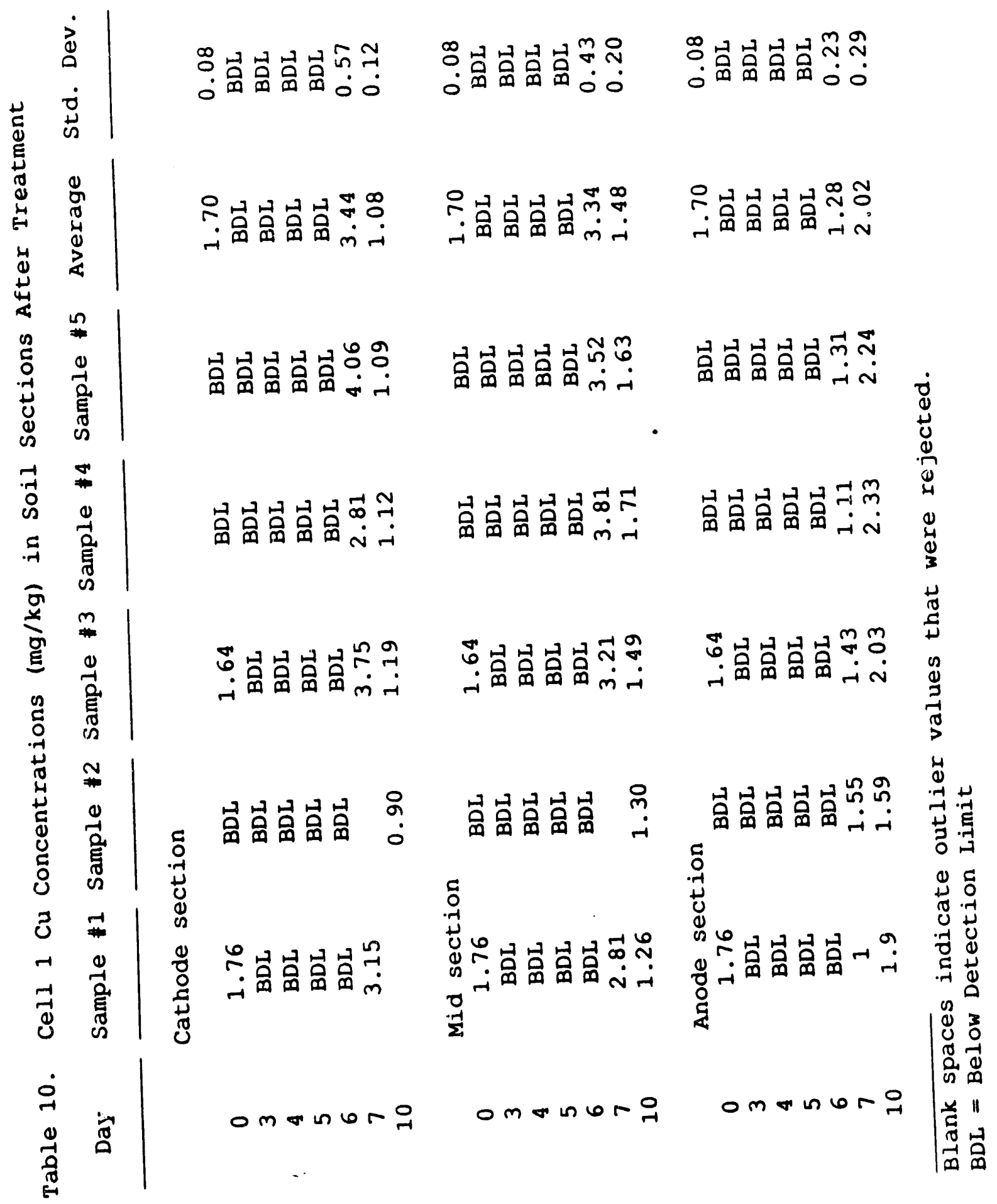




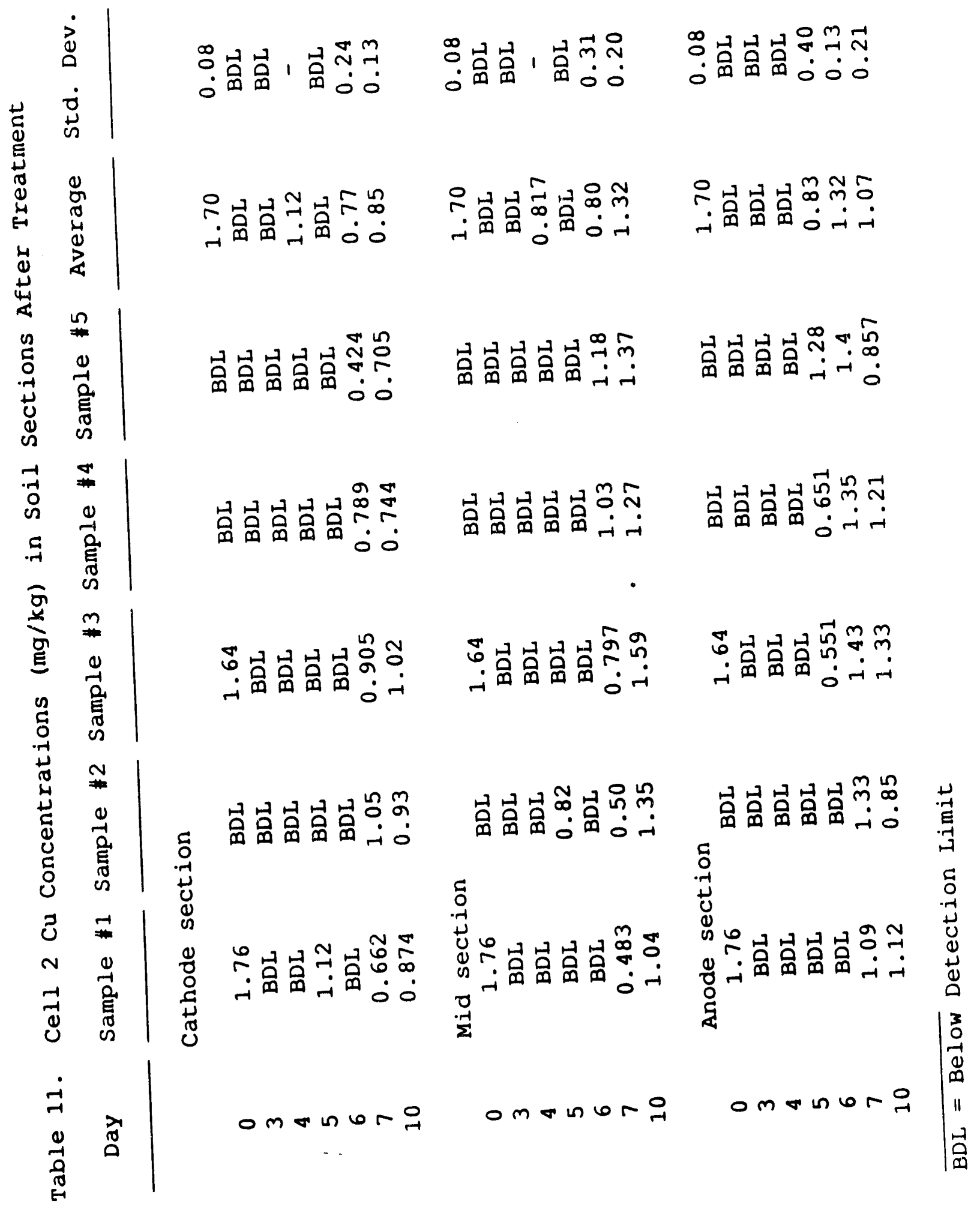




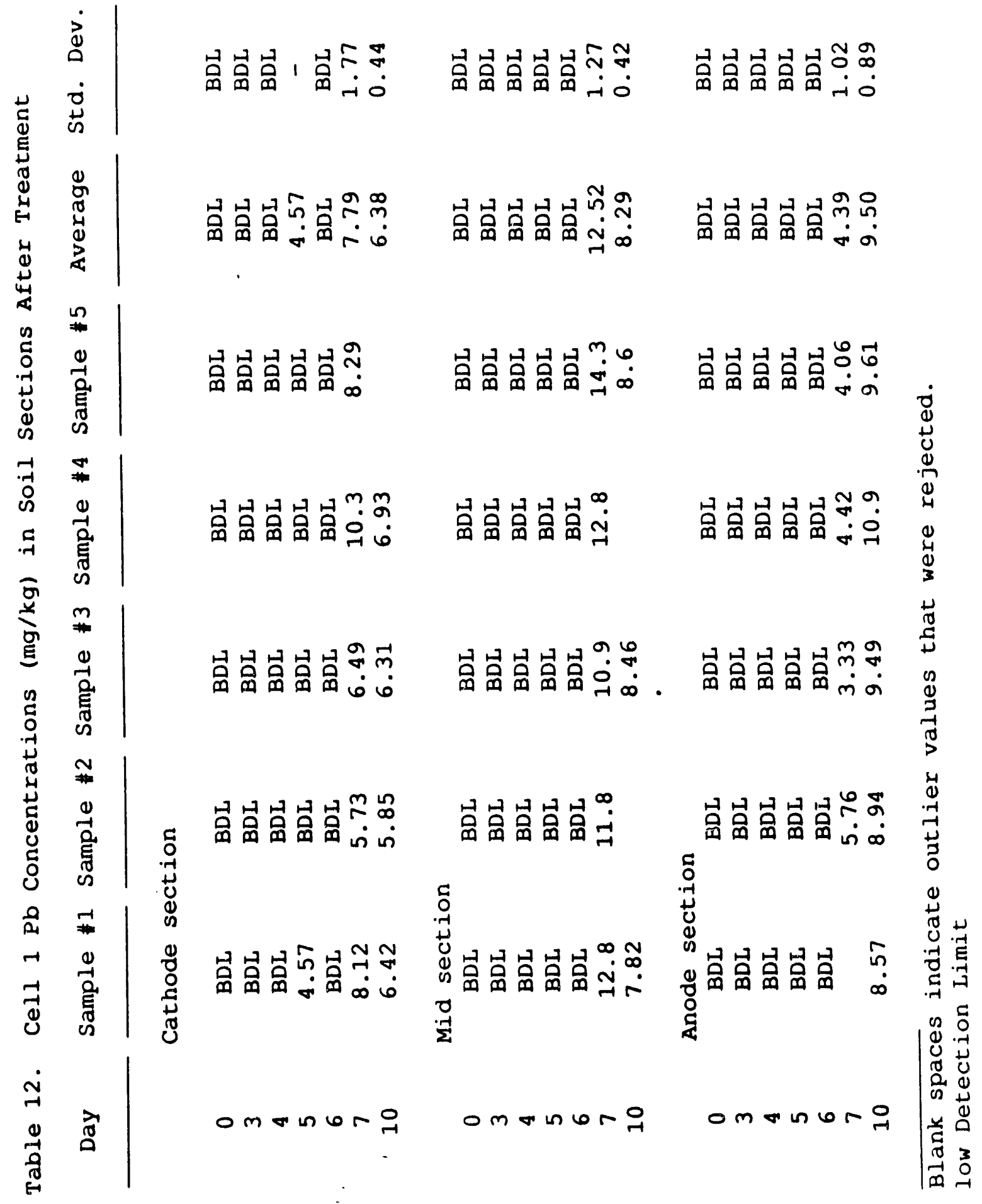




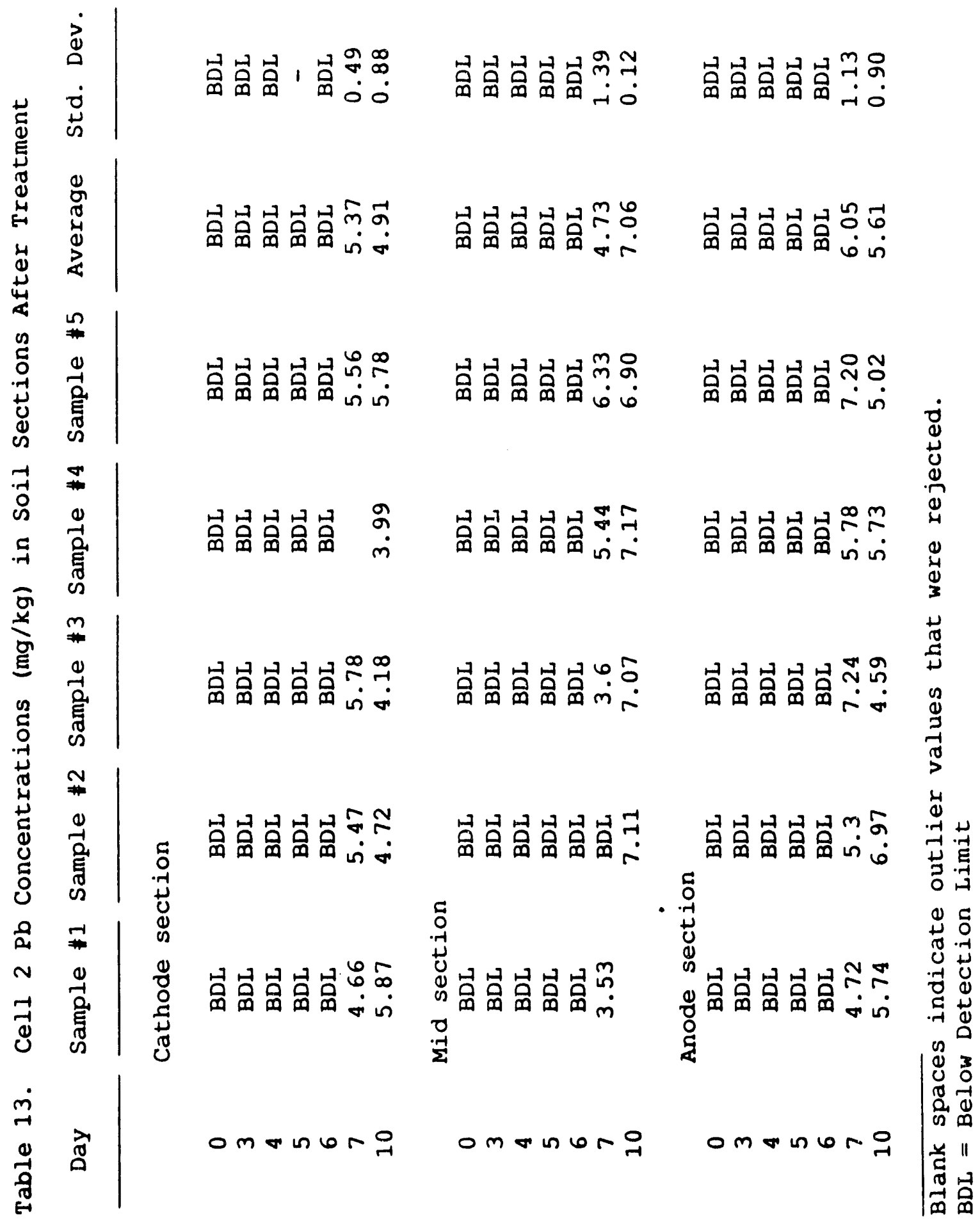




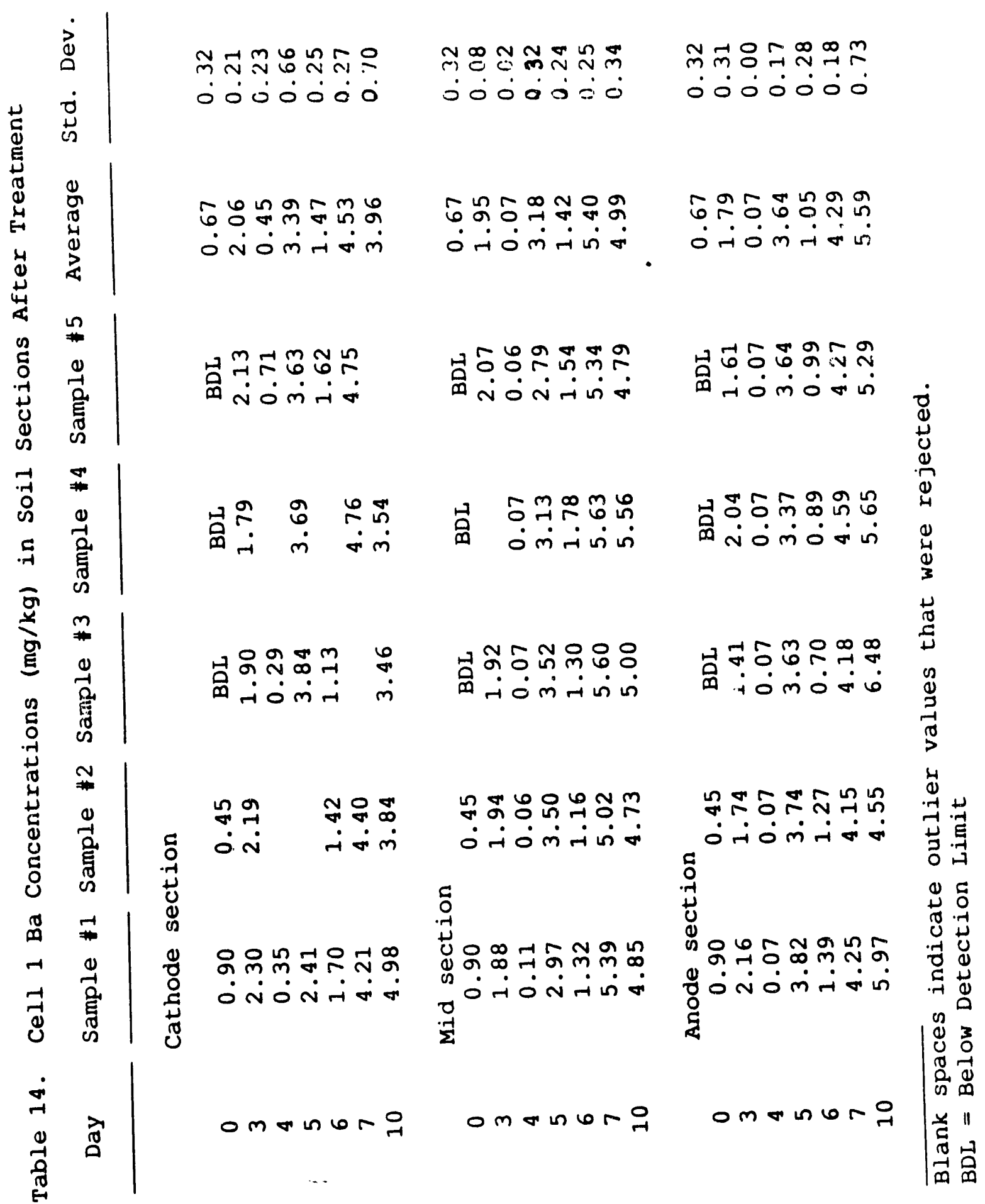




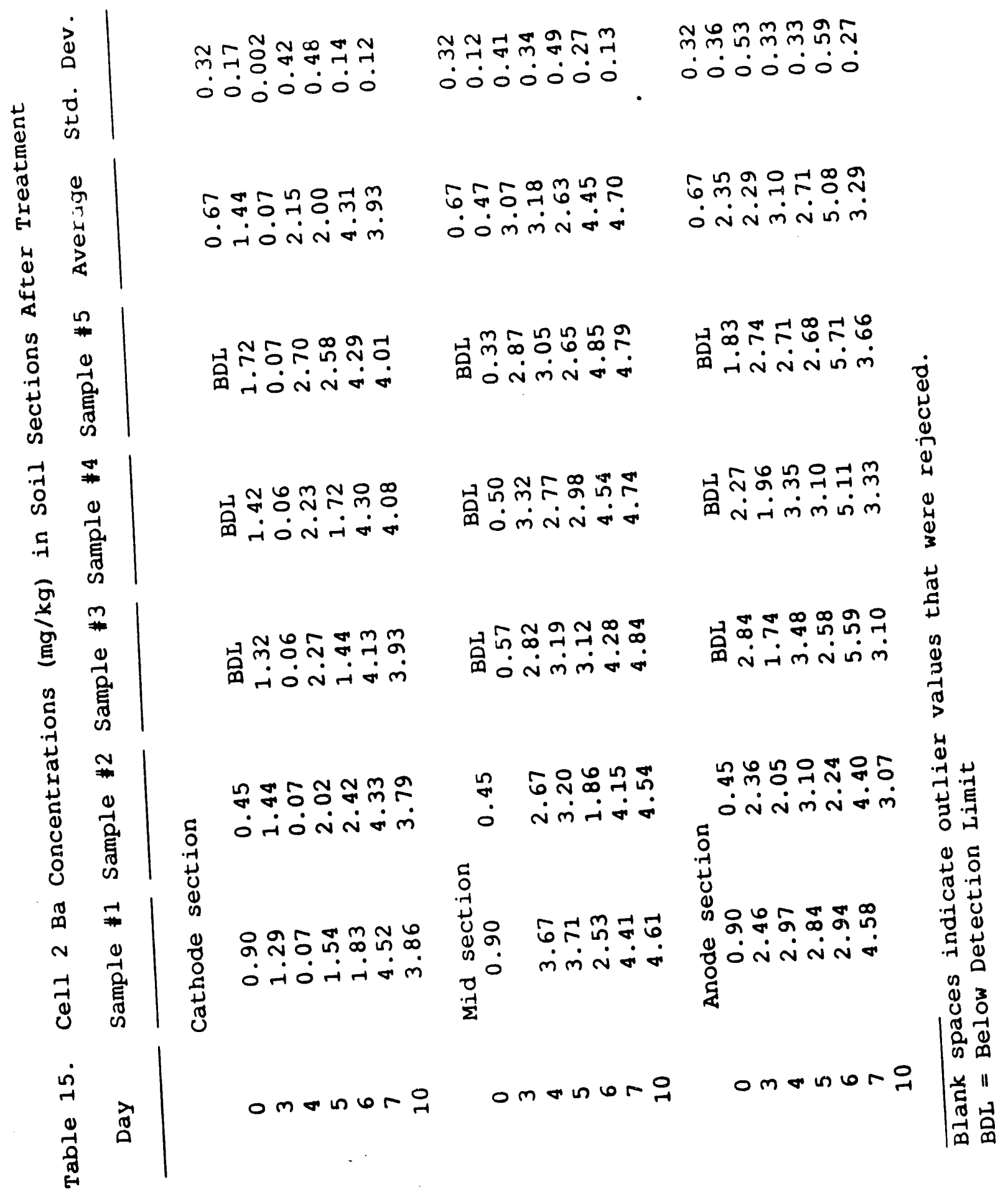




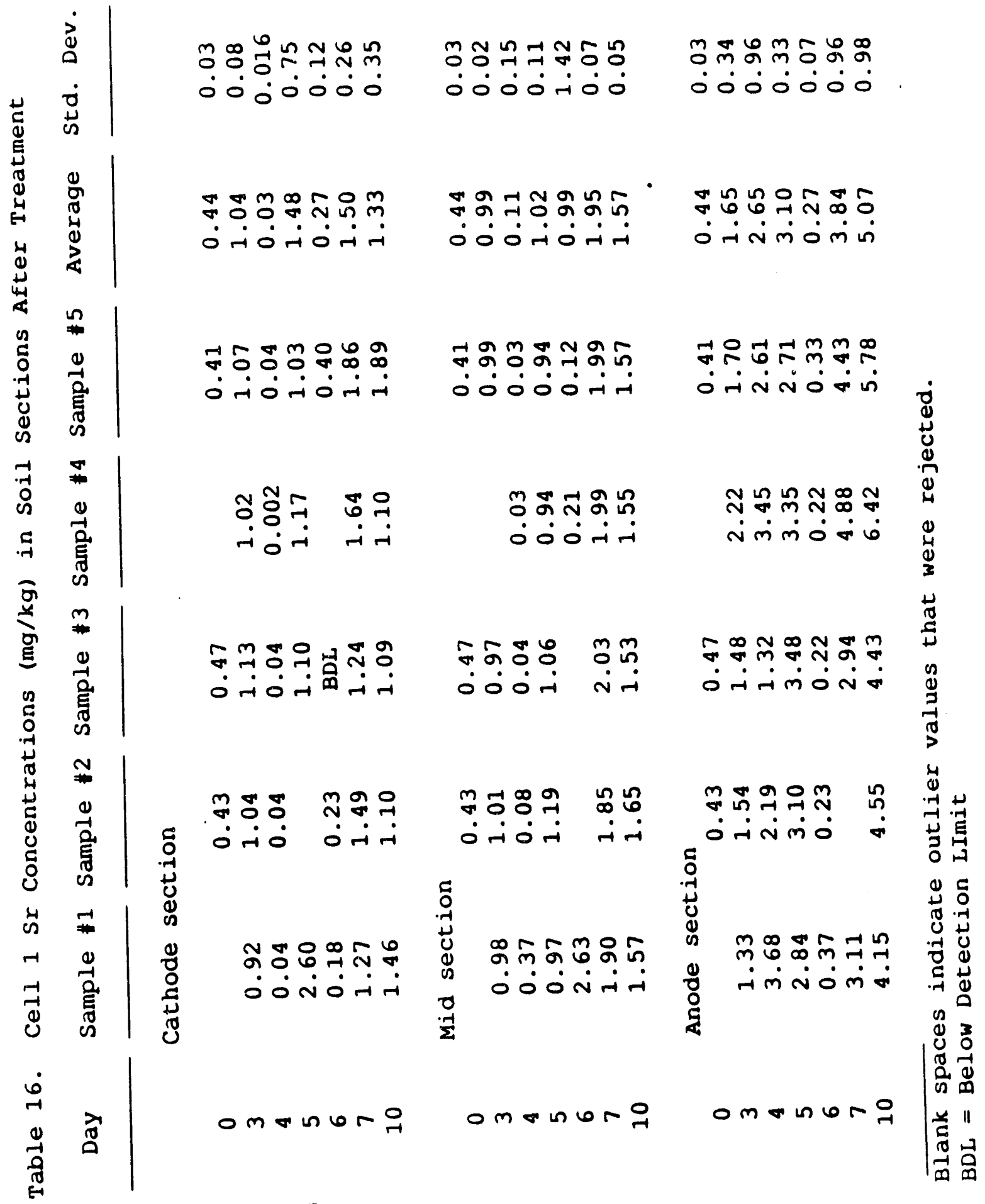




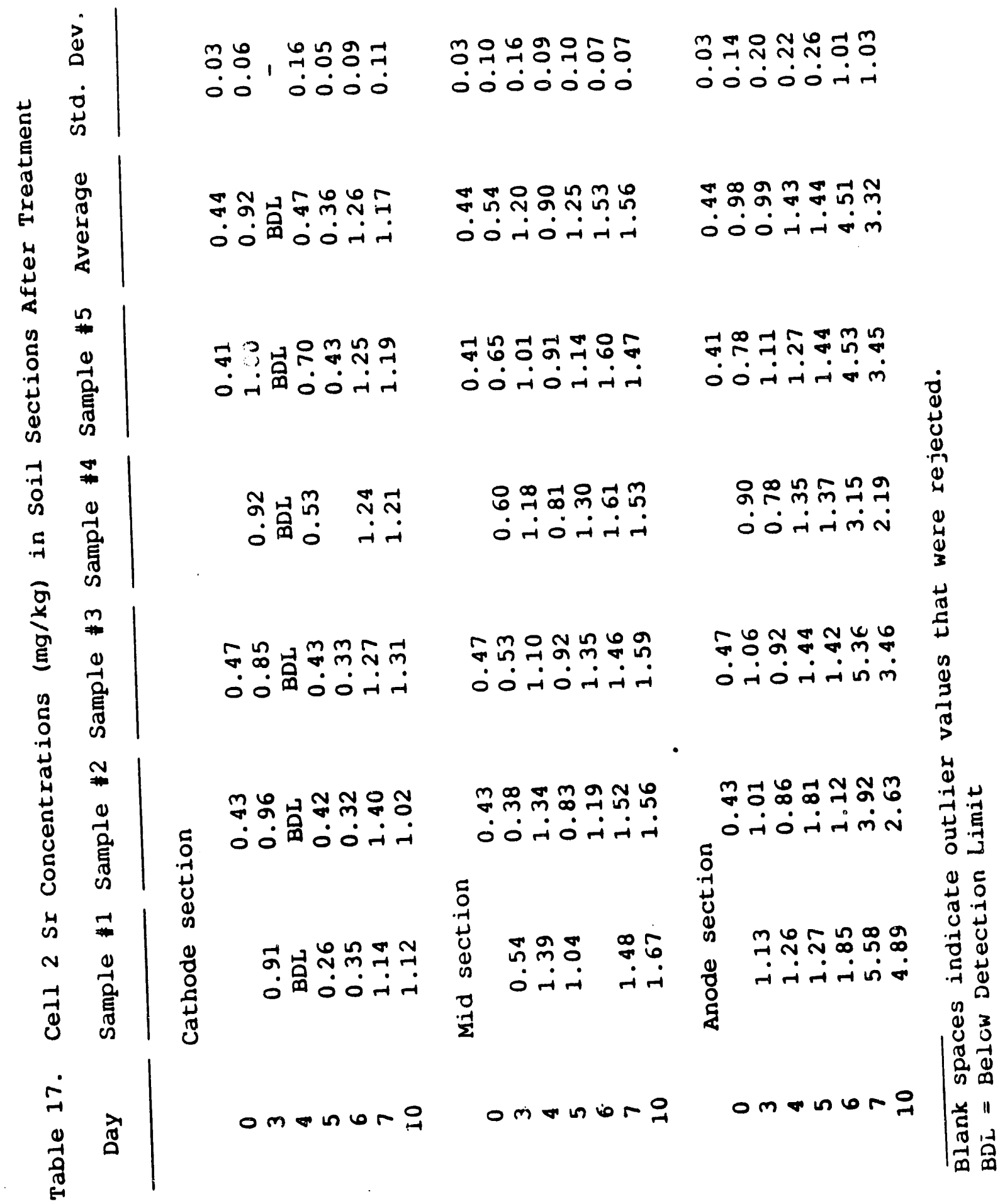




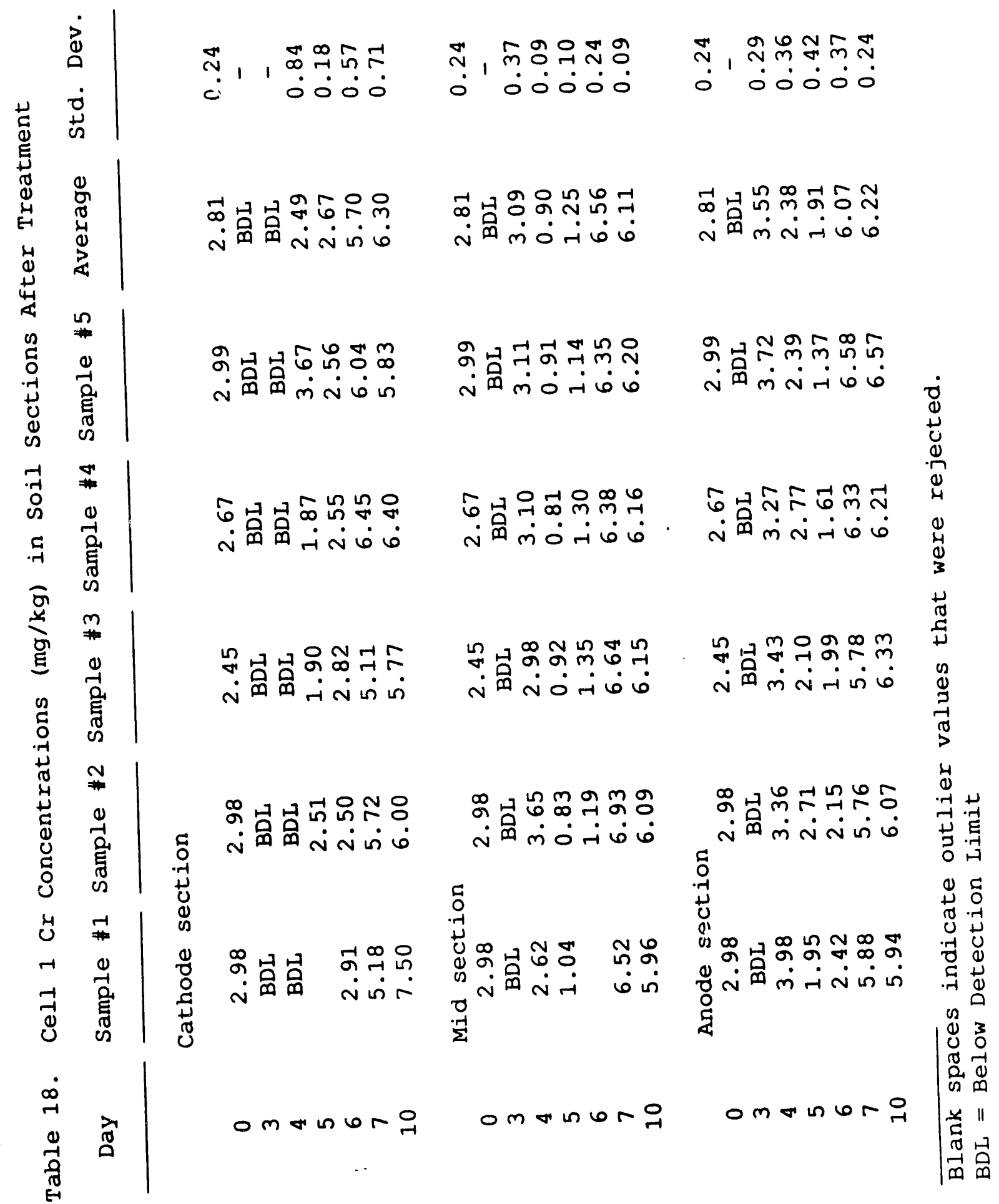




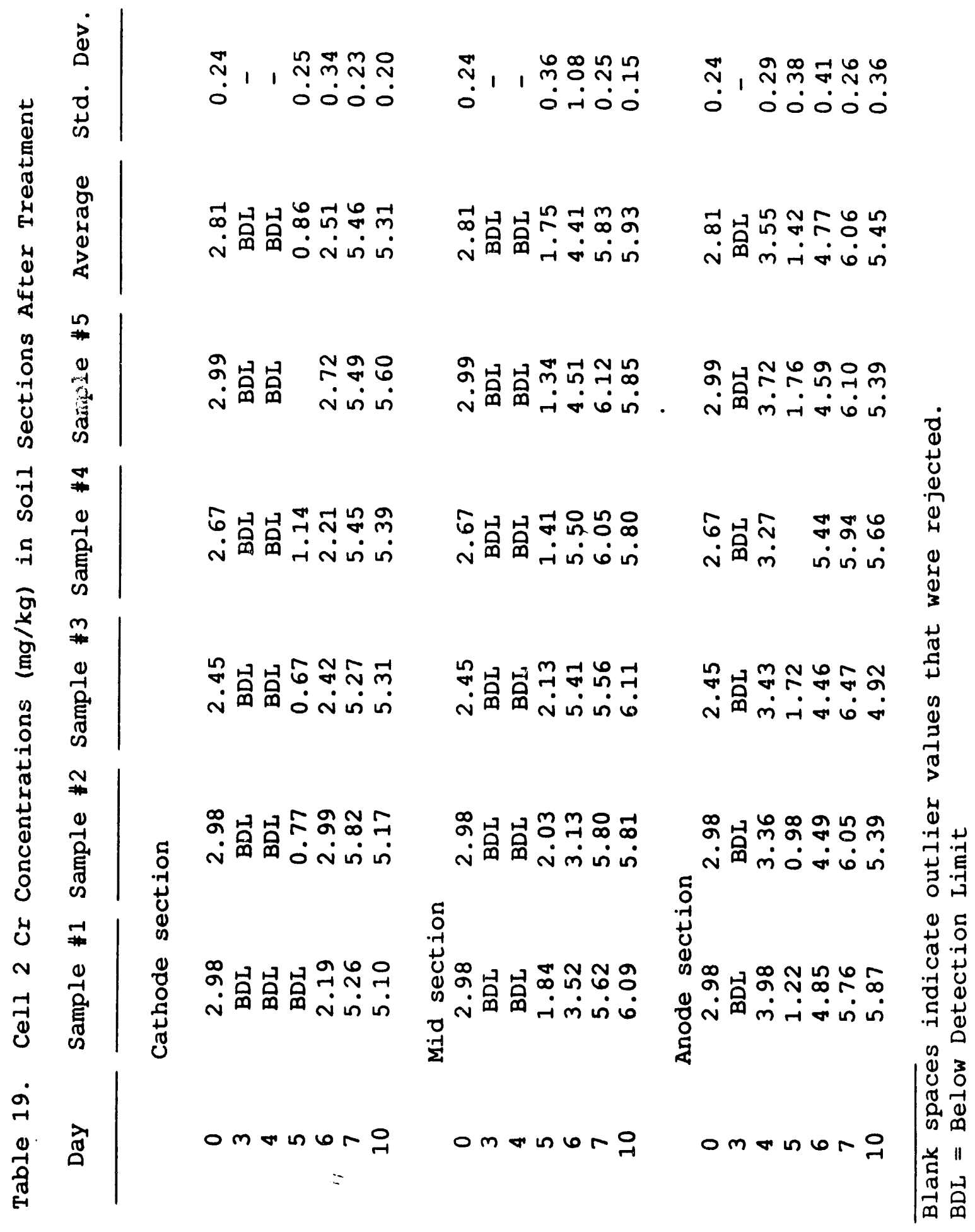




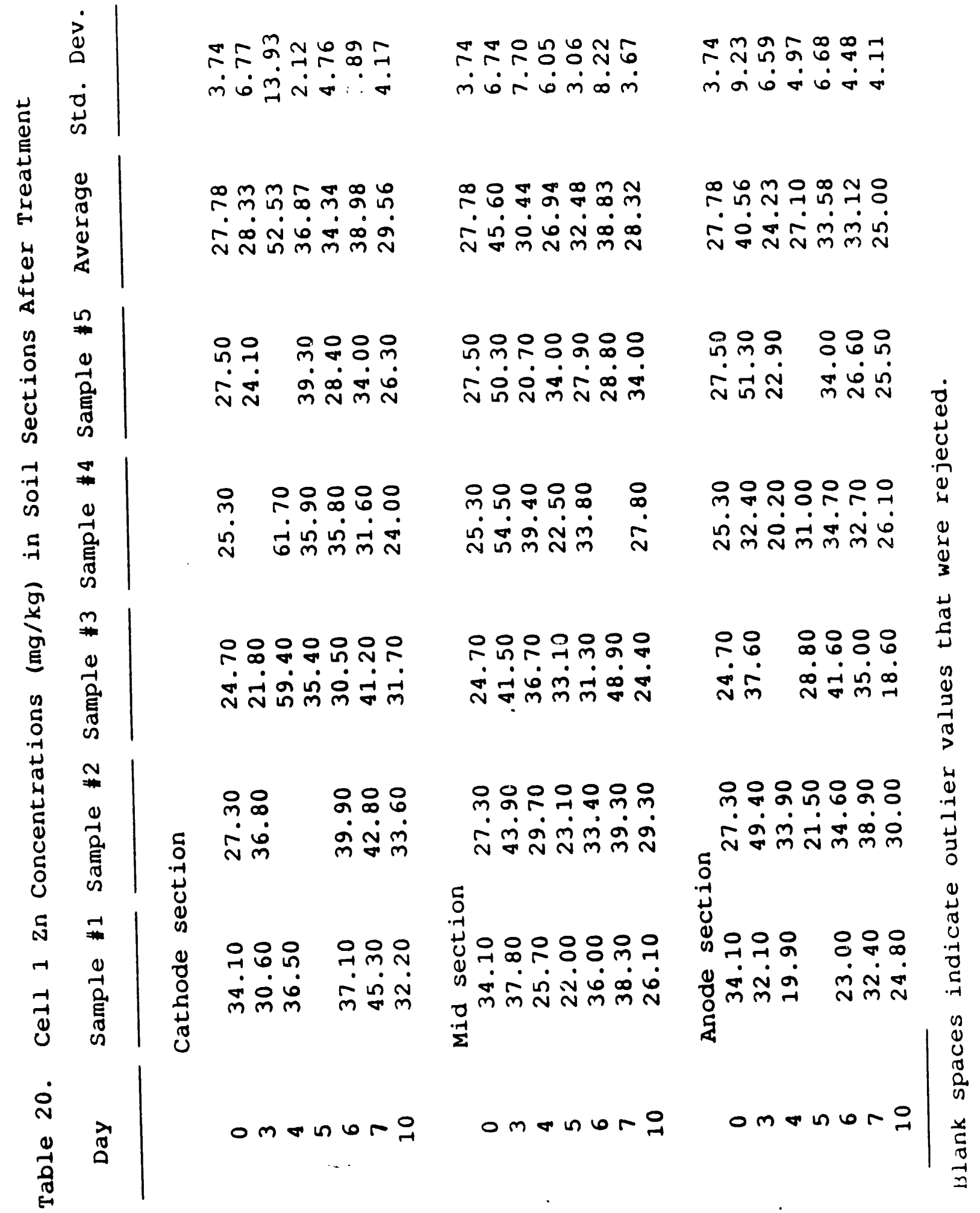




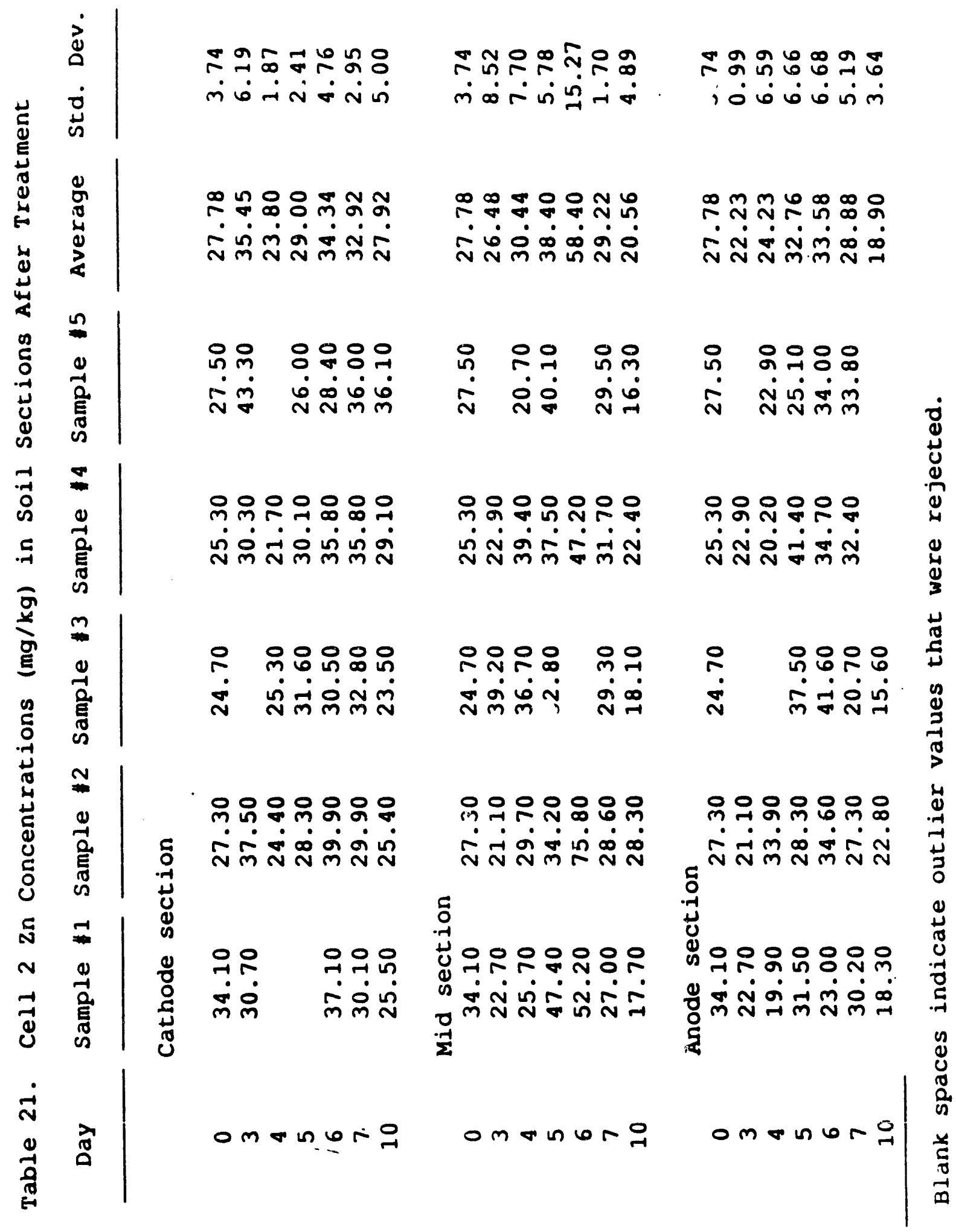




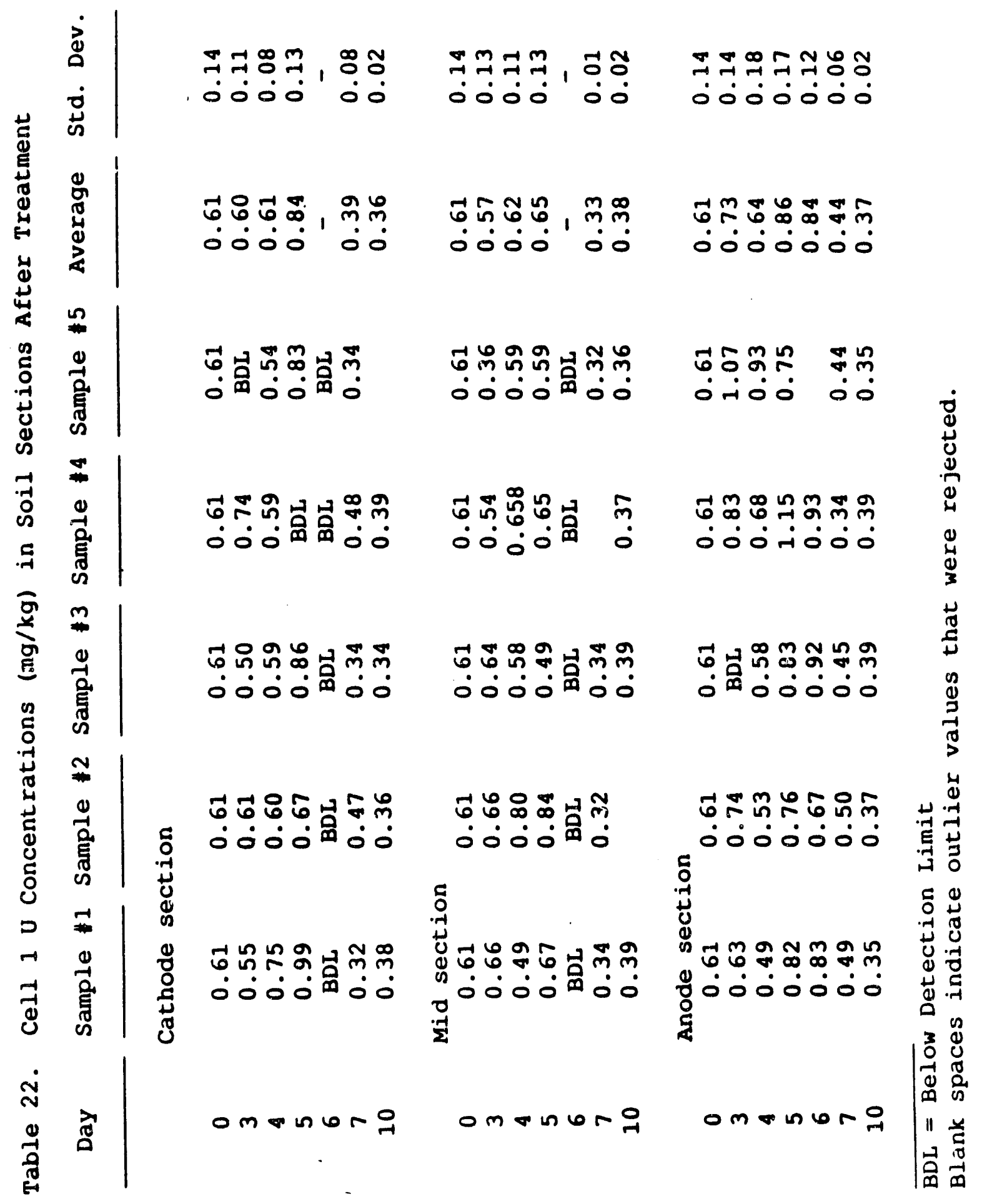




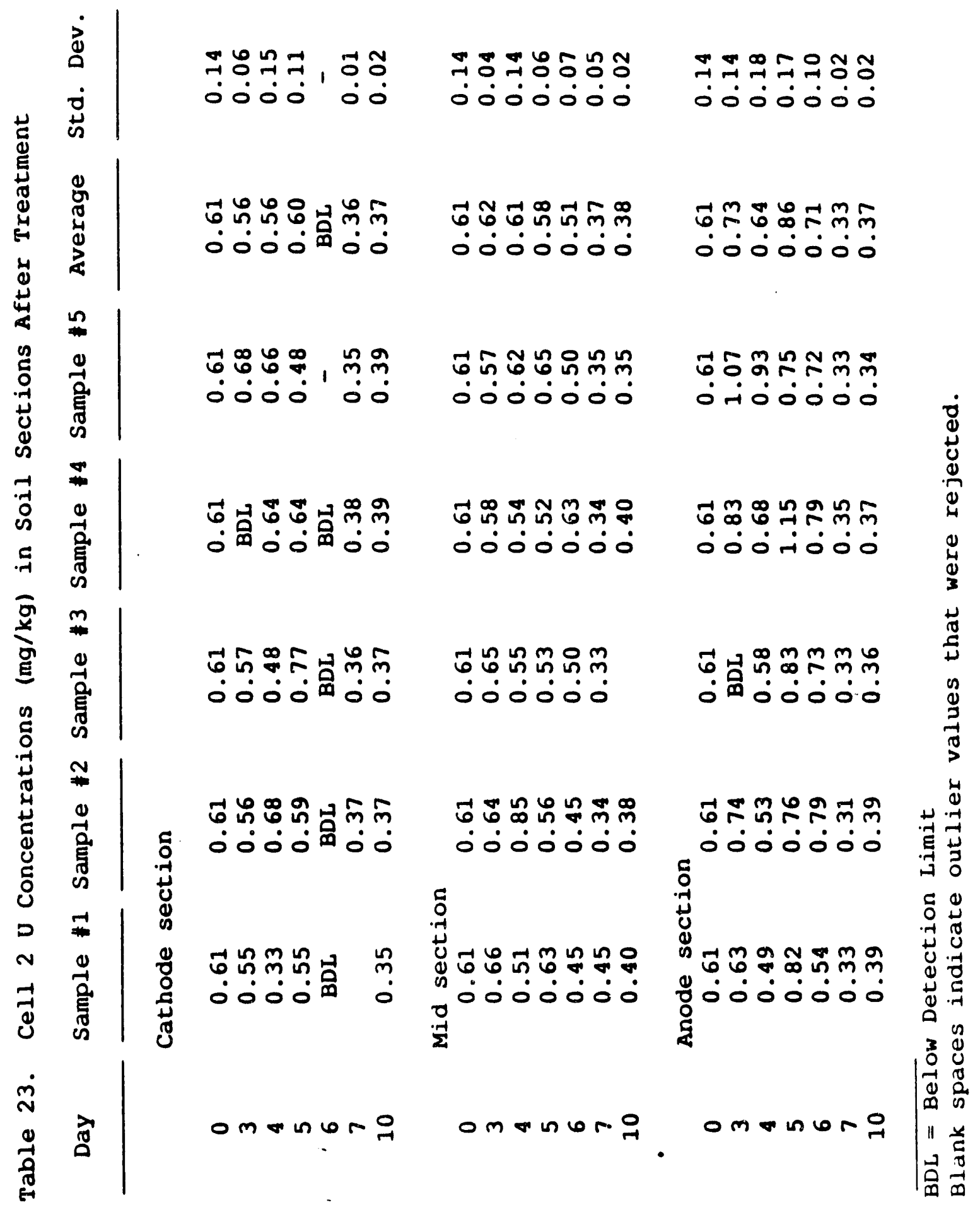


